\title{
ANNOTATED LIST AND NEW RECORDS OF MARINE AND FRESHWATER HALACARID MITES (HALACARIDAE, ACARI) FROM NORWAY
}

\section{IIse Bartsch}

\author{
Forschungsinstitut Senckenberg, Hamburg, Germany \\ e-mail: ilse.bartsch@senckenberg.de
}

\begin{abstract}
Records of halacarid species collected in the Norwegian Exclusive Economic Zone are summarized, and three new records are added. The list of halacarids includes 45 marine species in 15 genera and two species belonging to two freshwater genera. To each genus a short diagnosis is given, and to each species information about original descriptions, as well as recently published details about the morphology, geography and habitat is provided. The fauna of Norway, compared to that of other eastern North Atlantic coastlines, is poor. We can expect that in the course of further collecting activities, spanning from the tidal zone to deep-sea basins, the number of species will be distinctly more than doubled.
\end{abstract}

KEY WORDS: Halacaroidea, checklist, diagnoses, distribution, Norway.

DOI: 10.21684/0132-8077-2020-28-2-129-167

\section{INTRODUCTION}

Halacarid mites live in all geographical zones of the world: in polar, temperate and tropical areas, in the deep-sea (almost 7,000 m b.s.1.) as well as high up in the mountains $(5,000 \mathrm{~m}$ a.s. 1.$)$; on and in epigean as well as hypogean substrata; in the sea but also in fresh water. At present, more than 1,000 marine and about 50 freshwater species are known (Bartsch 2009).

The first halacarid mite was illustrated by Baster (1758). Descriptions of species followed in the middle of the nineteenth century (Johnston 1836; Gosse 1855a, b; Hodge 1860, 1863). All these species were from the seashore of Great Britain. The first halacarids from the Norwegian territories, Svalbard, were collected in 1889 during a French investigation of the Arctic benthos. In all, seven halacarid species were extracted from benthos samples (Trouessart 1902). The first freshwater halacarid species from Norway, Porohalacarus alpinus (Thor, 1910), was described a few years later (Thor 1910). Further detailed studies of the Norwegian marine halacarid fauna were carried out in the tidal and subtidal zone around Bergen (about 1925) and on beaches near Tromsö (August 1969-May 1971) (K. Viets 1927a, 1928a; Schmidt 1972; Bartsch 1978a; Bartsch and Schmidt 1979). Minor amendments to the knowledge of Norwegian halacarids species were made by Bartsch (1978b, 2003a); in recent years, Roy Wrånes added more species to the list of halacarids (Artsdatabanken 2019). In August to November 2016, Halldis Ringvold collected mussels, barnacles, algae and sediment around Vestfold, Stavanger, Bergen and Trondheim and extracted the halacarid mites. Still, the knowledge of the halacarid fauna of Norway is very poor.
In many parts of the world we can watch a change of flora and fauna (Gollasch and Nehring 2006) partly because of altered environmental parameters (e.g., raise of temperature), partly because of immigration and introduction of alien species. The present paper summarizes previous and adds new records to the list of halacarid species. It also outlines morphological and ecological characters of the species and refers to relevant taxonomic keys.

\section{MATERIALS AND METHODS}

The genera and their species are arranged in the alphabetical order. To each genus, a short outline of morphological characters is given, mainly restricted to easily recognizable characters of species present in the North Atlantic. More detailed information, covering the wide range of variants, as well as keys to halacarid genera, are given by Bartsch (2006a). The presentation of the species includes the information of the original description, recent and detailed presentations of morphological data, geographical records from Norway and worldwide, the habitats in which a species commonly is found, and biological data. Though not including all Norwegian species, the keys to species known from the United Kingdom, published by Green and MacQuitty (1987), are recommended. Major changes to the systematics of Halacaridae are: (1) the genus Thalassarachna, as used by Green and MacQuitty (1987), has been split into Thalassarachna and Halacarellus (Bartsch 1997a); (2) the north-eastern Atlantic species, once placed into the genus $\mathrm{Ar}$ hodeoporus, have been moved to Maracarus (Bartsch 2016a). Also, Rhombognathides merri- 
mani turned out to be a junior synonym of $R$. trionyx (Trouessart, 1899) (cf. Bartsch 2009).

Abbreviations used in the presentation of morphological details: AD - anterior dorsal plate; $\mathrm{AE}$ — anterior epimeral plate; $\mathrm{AP}$ — anal plate; ds- 1 to ds-6 - first to sixth pair of dorsal idiosomal setae, numbered from anterior to posterior; EI to EIVepimera I to IV; GA-genitoanal plate; GOgenital opening; glp-1 to glp-5-gland pores 1 to 5 , numbered from anterior to posterior; $\mathrm{GP}$ - genital plate; OC - ocular plate(s); P-1 to P-4 - first to fourth palpal segment, numbered from basal to apical; pas - parambulacral seta(e); PD—posterior dorsal plate; PE—posterior epimeral plate(s); pgsperigenital setae; sgs - subgenital setae. The legs, their segments and claws are numbered from I to $\mathrm{IV}$, from anterior to posterior. The leg segments are trochanter, basifemur, telofemur, genu, tibia, and tarsus. The number of dorsal setae on the tarsi includes the solenidion. Rarely occurring numbers of setae are in parentheses. A question mark (?) is added in case the data are in need of verification.

The presentation of geographical records from Norway starts with the ones from Oslofjord and follows the coastline until Gamvik and Svalbard. The records of countries outside Norway are arranged in the alphabetical order.

\section{RESULTS}

\section{Halacaridae: general information}

Halacarids belong to the mite suborder Prostigmata. The family name Halacaridae was introduced by Murray (1877) for mites 'living habitually under the sea, having either a stiff or more or less rigid, cuirassed skin, and with their legs springing from the outer margin of the body'.

Halacarids can be distinguished from other mites on the basis of a combination of characters, namely: (1) the anterior two pairs of legs are directed forward, the posterior two pairs backward, the gap between insertion of legs II and III equals at least one third of the width of the idiosoma; (2) the legs insert marginally or dorsomarginally, not ventrally; (3) adults have four pairs of six-segmented legs, and (4) the idiosoma of the majority of species has six pairs of dorsal setae, though species with no more than two or up to ten pairs are known.

\section{Checklist of marine halacarids recorded from Norway}

Forty-seven named halacarid species in 17 genera are recorded from the Exclusive Economic
Zone of Norway; 45 species are marine, two live in freshwater. The marine genera and the number of species (in parentheses) are: Agauopsis (1), Anomalohalacarus (1), Bradyagaue (1), Copidognathus (8), Halacarellus (6), Halacarus (1), Isobactrus (4), Lohmannella (4), Makarovana (1), Maracarus (1), Metarhombognathus (1), Rhombognathides (5), Rhombognathus (2), Simognathus (1), and Thalassarachna (8), the freshwater genera are Porohalacarus (1) and Porolohmannella (1). The species, along with the relevant collecting data, are summarized in Table 1.

\section{Genus Agauopsis K. Viets, 1927}

Diagnosis. Generally intensely armoured, with only narrow areas of striated integument between the plates. Third palpal segment with medial spur or seta. Leg I wider and longer than following legs. Genu I distinctly shorter than telofemur and tibia. Tibia I with three to five blunt spines, telofemur I with zero (one species) to four such spines. Tarsus I with spine on medial, not on ventral flank.

Agauopsis corallina Bartsch, 2003

Agauopsis corallinus Bartsch, 2003a: 118-122, figs. 1-14.

Short description. Length $345 \mu \mathrm{m}$ (male). Anterior margin with tricuspid process. Porose areolae (with rosette pores) small, on the PD almost restricted to posterior part between the gland pores. Telofemur I with one long ventral and three short medial spines, tibia I with one long and one short ventral and three rather short medial spines. Tibiae of following legs with three bristle-like ventral setae. Tarsi II-IV with slender ventral seta.

Norwegian record. Sula Ridge, $64^{\circ} 05^{\prime} \mathrm{N}$, $08^{\circ} 02^{\prime}$ E, $285 \mathrm{~m}$ depth (Bartsch 2003a).

Further records. None.

Biology. Collected from a deep-water reef formed mainly by colonies of the stony coral Lophelia pertusa (Linnaeus, 1758) (Scleractinia).

Remarks. Agauopsis corallina is momently the only record of an Agauopsis species from north of $58^{\circ} \mathrm{N}$. The species is most similar to the two north-eastern Atlantic species A. minor (Trouessart, 1894) and A. meteoris Bartsch, 1973, but in A. corallina the porose areolae on the dorsal plates are smaller, on the PD almost restricted to the posterior part; in the two other species, the areas with rosette pores extend within the costae anteriad to or beyond the level of the posterior corner of the OC (Trouessart 1894a; Bartsch 1973a, 2001a). 


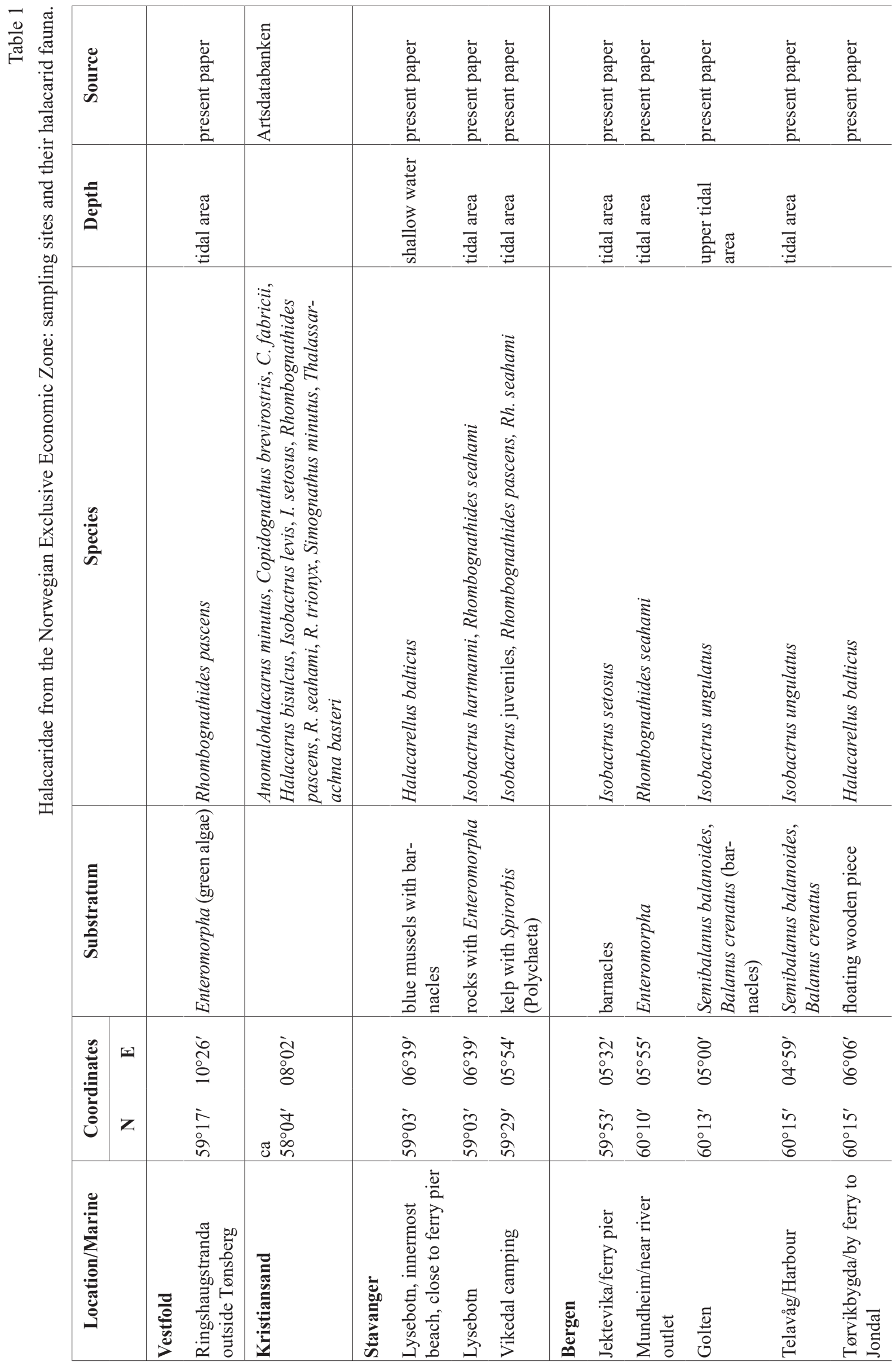




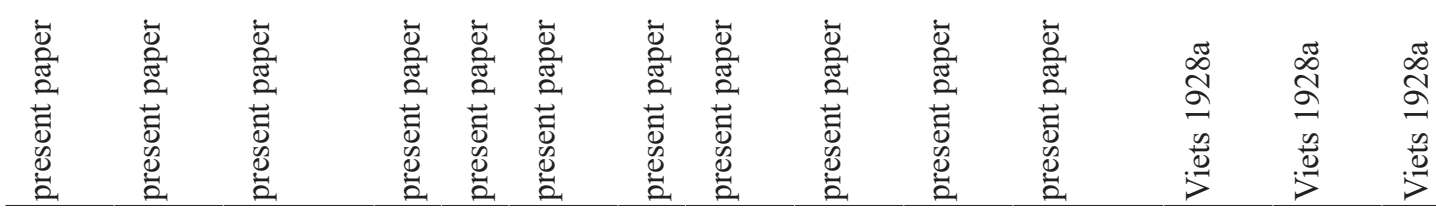

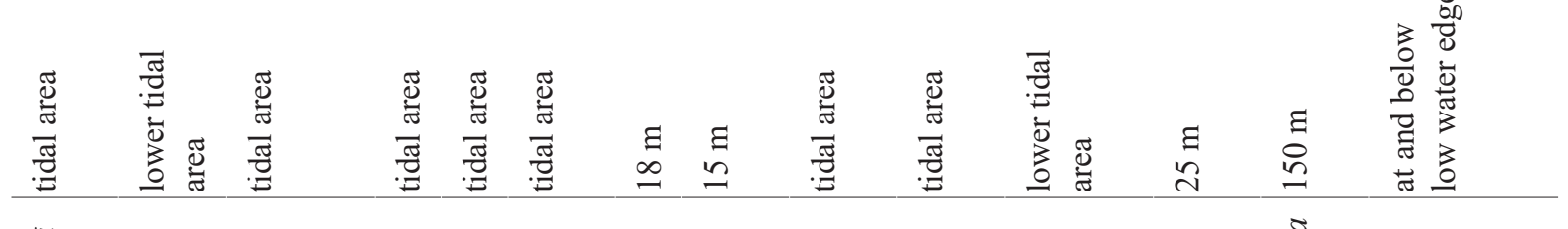
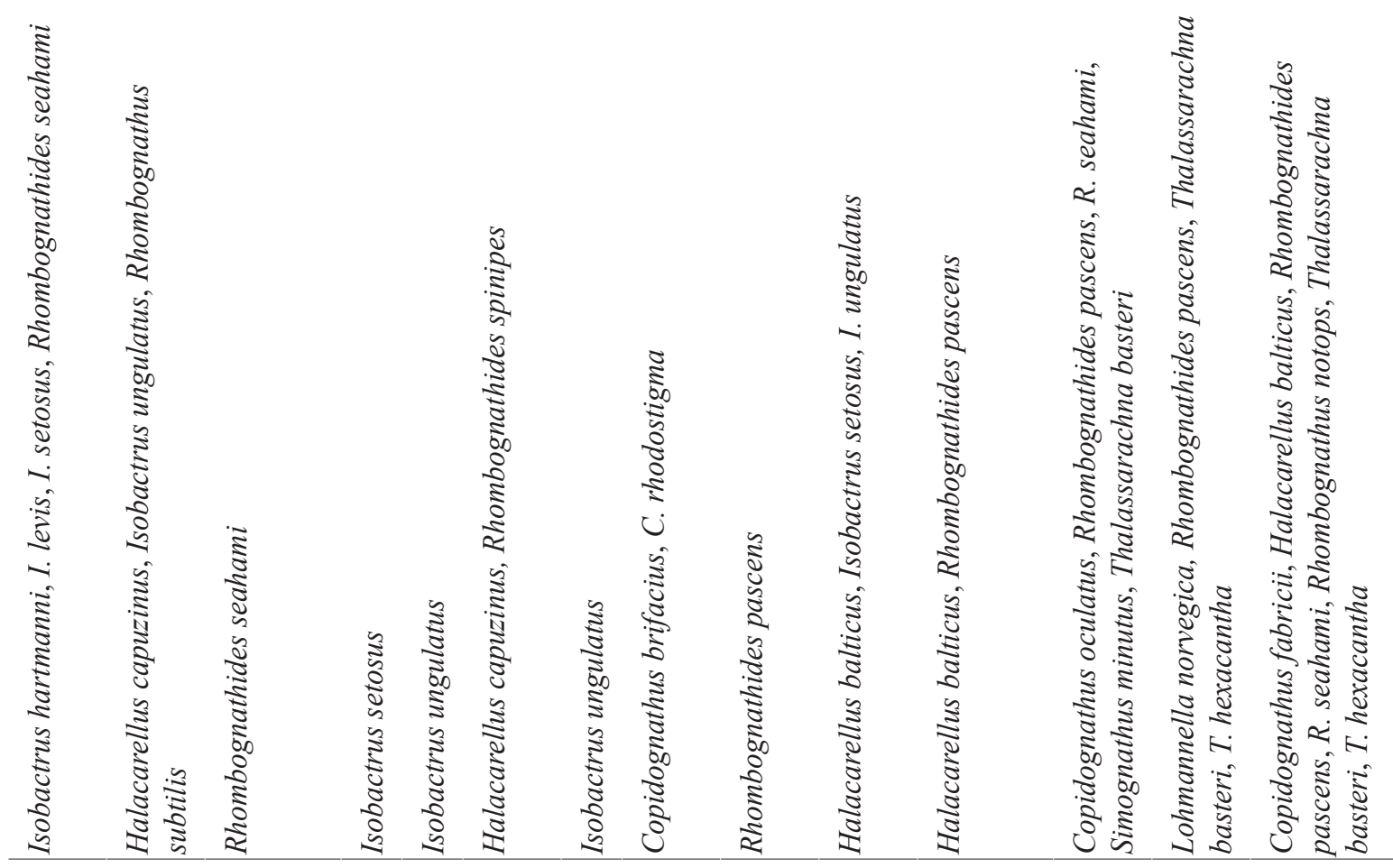

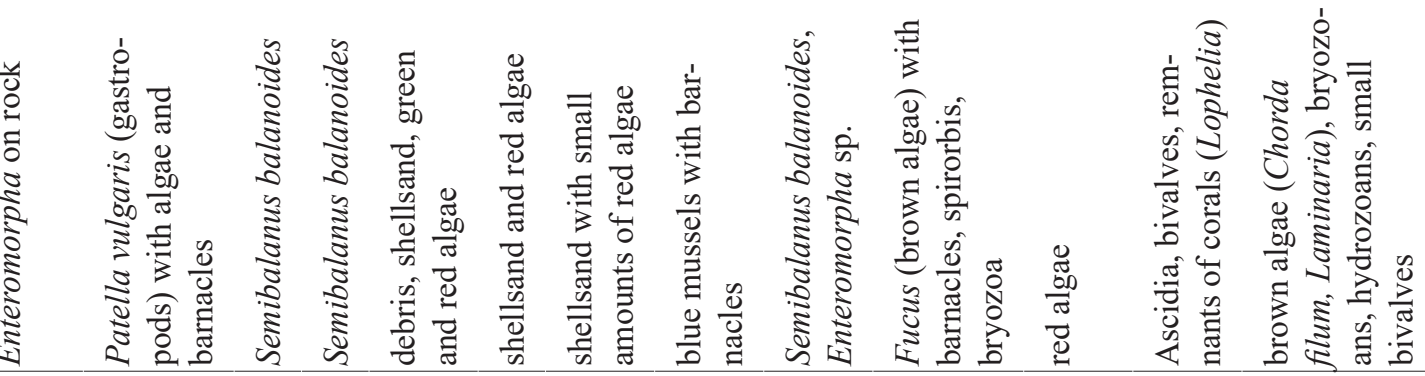

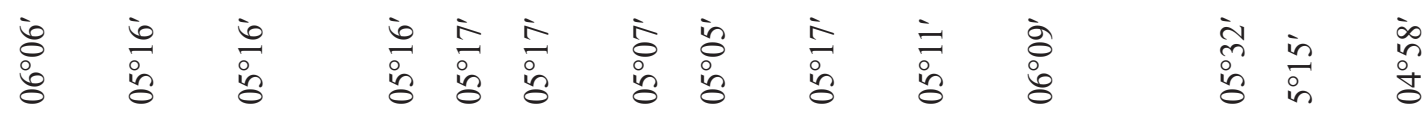

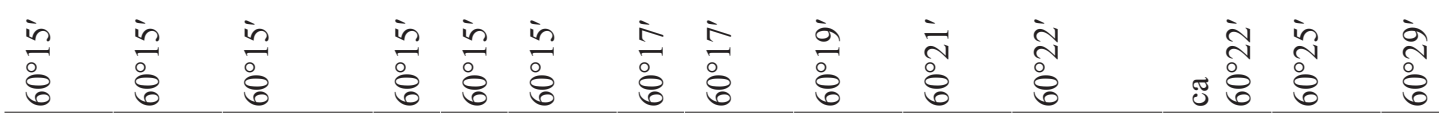

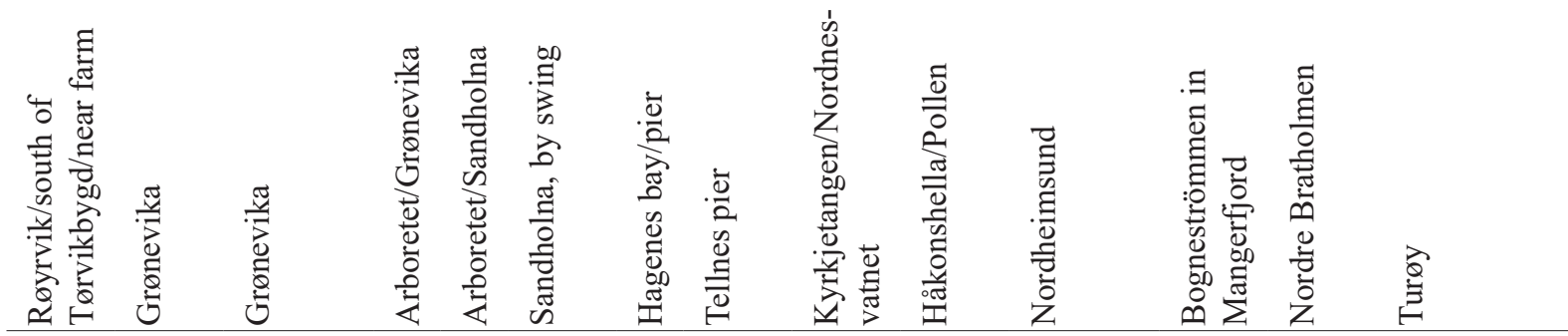




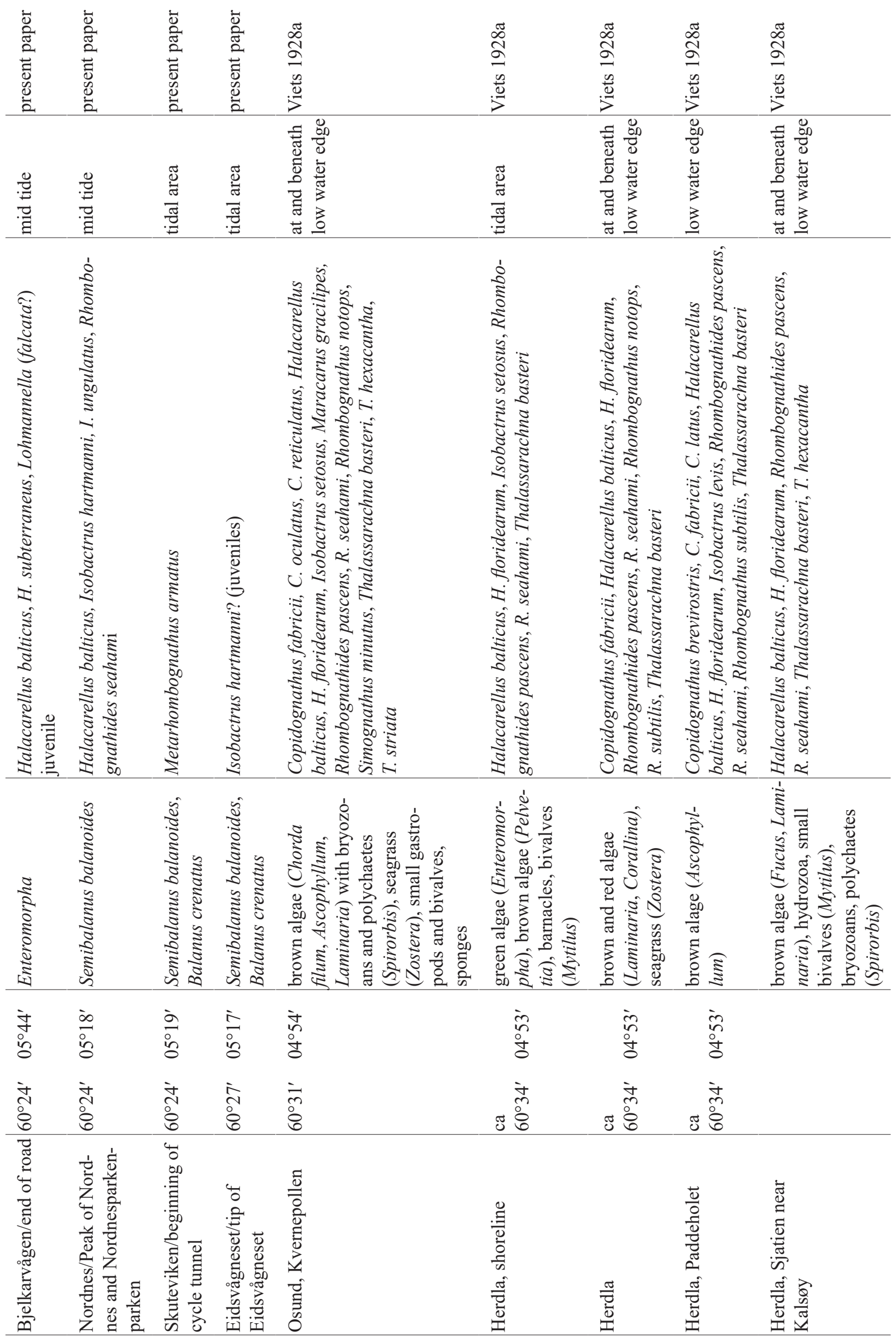




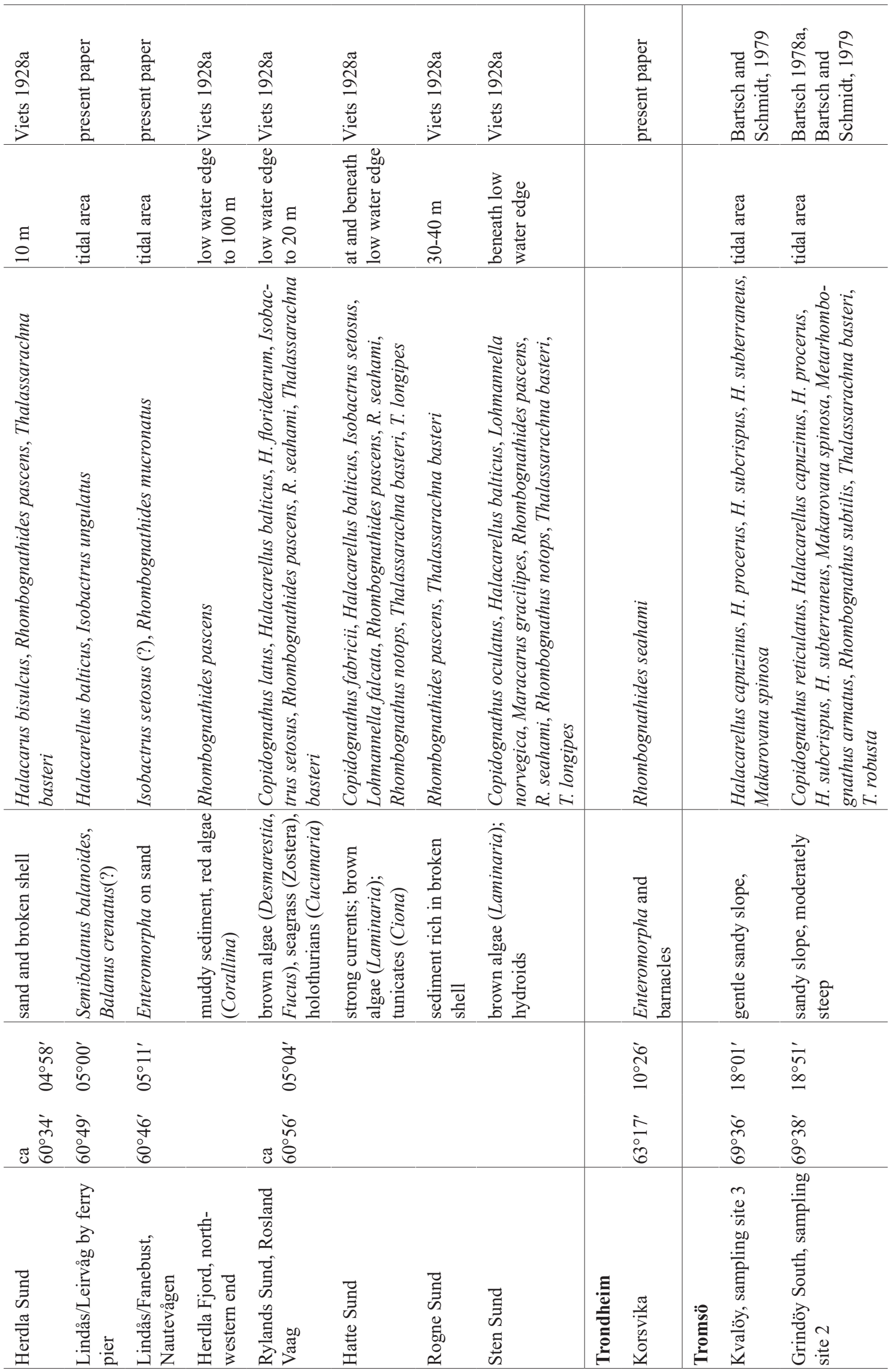




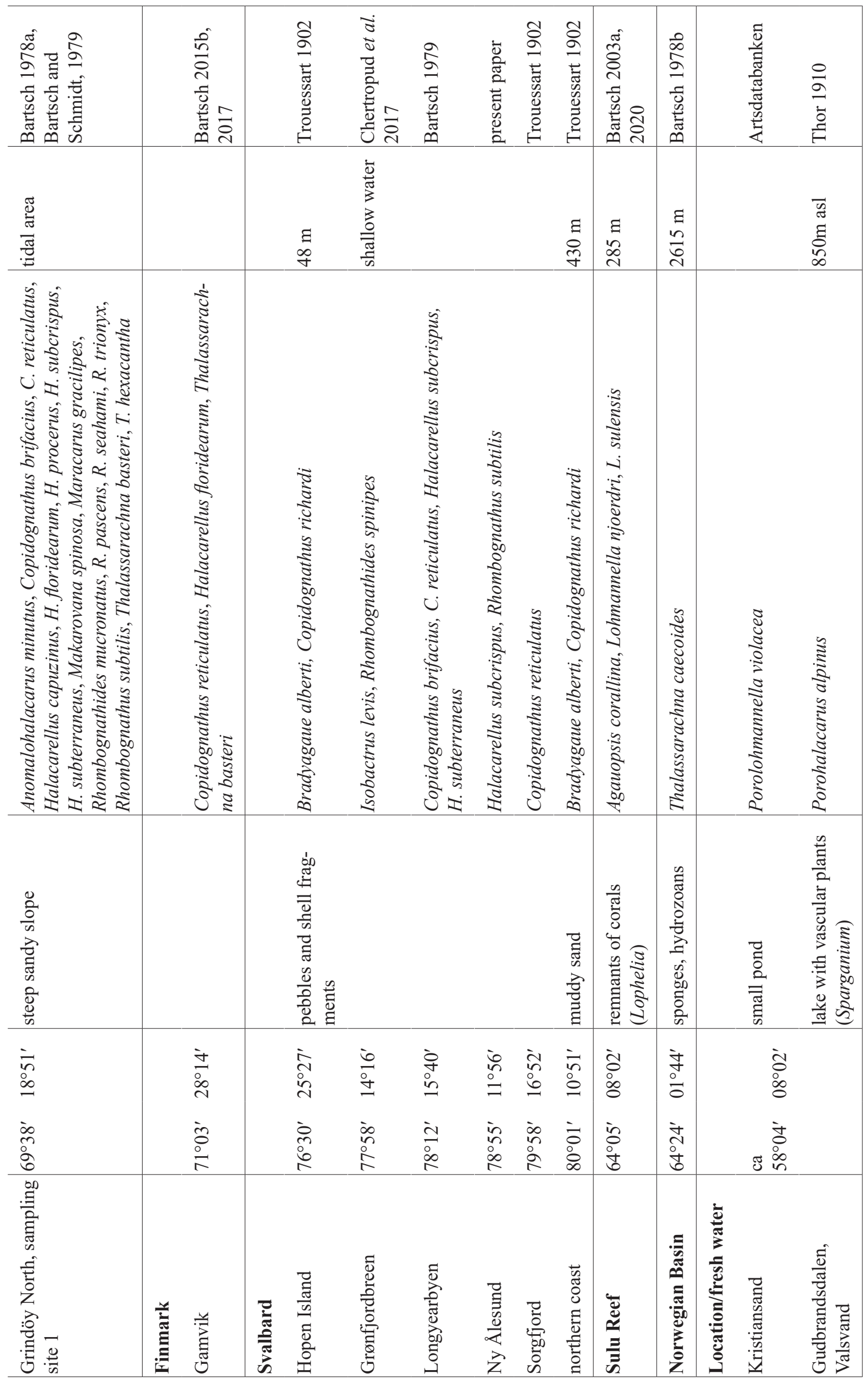




\section{Genus Anomalohalacarus Newell, 1949}

Diagnosis. Idiosoma, gnathosoma and legs slender. AD and PD as well as two anterior pairs and two posterior pairs of legs situated near ends of idiosoma. Plates small; dorsum and venter of body dominated by flexible, striated integument. $\mathrm{AE}$ mostly divided in the median into a right and left half. Female genital plate divided. Third palpal segment with medial spur. Telofemora, genua and tibiae similar in length. Tarsus I with small ventromedial spur (rarely two spurs) and a pair of short eupathidia.

Anomalohalacarus minutus Bartsch, 1976

Anomalohalacarus minutus Bartsch, 1976a: 659-661, figs. 32-46.

Anomalohalacarus minutus, Green and MacQuitty 1987: 66, 67, fig. 23A-E.

Short description. Length $210-287 \mu \mathrm{m}$. PD divided in two halves. Female genital groove masked. Male GA oviform, anteriorly narrowed, with 9-11 pairs of pgs. Rostrum short, far from reaching to end of P-2. In middle of ventral flank of tibia I one short spur and, adjacent, one short seta. Tibia II ventro-apically with a slender and a bipectinate seta, tibiae III and IV with two bipectinate setae. Telofemur II with three dorsal and zero ventral setae.

Norwegian records. Kristiansand (Artsdatabanken 2019); Tromsö (north-eastern edge of Grindöy, from sandy moderately exposed beach slope) (Schmidt 1972; Bartsch and Schmidt 1979).

Further records. North-eastern Atlantic, North Sea and the Baltic: France (Brittany), Germany (Sylt, Schilksee), England (Yorkshire) (Bartsch 1976a, 1985a).

Biology. Anomalohalacarus minutus, just as the other Anomalohalacarus species, is specialized to life within the interstitia of medium grained sediments. Most records are from tidal and shallow subtidal sandy deposits.

Remarks. At present, this is the only Anomalohalacarus species known from Norway but seven more species, with records from the English Channel, the Irish Sea, the North Sea (England), and Skagerrak (Sweden) (Monniot 1967; Bartsch 1985a, 1991a; Bartsch and Schmidt 1979), are likely to be found in Norwegian waters.

\section{Genus Bradyagaue Newell, 1971}

Diagnosis. Body slender, length about twice the width. Posterior epimeral plates enlarged, their length equalling more than one-third of body length, opposing margins of right and left plate truncate. Gnathosoma slender. Telofemora, genua and tibiae of legs often with narrow cerotegumental layer. Tarsi III and IV curved. Tarsi II to IV with wide, bidentate median claw.

\section{Bradyagaue alberti (Trouessart, 1902) \\ Halacarus (Leptospathis) alberti Trouessart, 1902: 67-68. \\ Bradyagaue alberti, Bartsch 1991b: 1348-1350, figs. 18-26.}

Short description. Length $880 \mu \mathrm{m}$ (female). Body slender, with dorsal plates $\mathrm{AD}$, pair of OC and PD separated by rather small areas of striated integument. Opposing margins of $\mathrm{AD}$ and $\mathrm{PD}$ arched. Posterior margin of AE widely rounded. Tibia I to IV with 4, 4, 3, 3-2 ventral setae. Setae on tibiae III and IV on setigerous processes.

Norwegian records. Hopen Island, found off the south-eastern coast of Svalbard, $76^{\circ} 30^{\prime} \mathrm{N}$, $25^{\circ} 27^{\prime} \mathrm{E}, 48 \mathrm{~m}$, amongst pebbles and shell fragments and off northern coast of Svalbard, $80^{\circ} 01^{\prime} \mathrm{N}$, $10^{\circ} 51^{\prime} \mathrm{E}, 430 \mathrm{~m}$, in muddy sand; stations 970 and 1012 of the Cruise of the Yacht Princesse-Alice in 1898 and 1899 (Trouessart 1902).

Further records. None. Specimens once mentioned from the Great Meteor Seamount (Bartsch 1973a) proved to belong to B. meteoris Bartsch, 1991 (Bartsch 1991b).

Biology. Found in sediment samples, in muddy as well as gravelly sand from a depth of 48 and $430 \mathrm{~m}$. Bradyagaue species are expected to live on hydrozoans (cf. Bartsch 2016b, fig. 2C); and this is also true for $B$. alberti.

Remarks. Three Bradyagaue species are known from the North Atlantic, namely, $B$. alberti from Svalbard, B. meteoris Bartsch, 1991 from the Great Meteor Seamount, ca $29^{\circ} \mathrm{N}, 28^{\circ} \mathrm{W}, 300-340 \mathrm{~m}$, and B. stocki Bartsch, 1992 from the Cape Verde Islands, $16^{\circ} 35^{\prime} \mathrm{N}, 24^{\circ} 36^{\prime} \mathrm{W}, 1,200 \mathrm{~m}$ (Trouessart 1902; Bartsch 1991b, 1992). Bradyagaue alberti (length of female $880 \mu \mathrm{m}$ ) is larger than B. meteoris (length of females 545-625 $\mu \mathrm{m}$ ) and B. stocki (length of female $595 \mu \mathrm{m}$ ), the anterior margin of the PD is arched instead of slightly tapering. Tibiae III and IV of $B$. alberti have three and two to three ventral setae, respectively, in $B$. meteoris and $B$. stocki these two segments bear four ventral setae.

\section{Genus Copidognathus Trouessart, 1888}

Diagnosis. Dorsal and ventral plates often panelled or with markedly porose areas, rarely 
smooth. P-2 with one posterior seta. No seta on P-3. Genu I shorter than adjacent telofemur and tibia. Tibiae I and II each with three ventral and four dorsal setae, tibiae III and IV with two ventral and three dorsal setae. Tarsus I with one ventral seta and a pair of apical eupathidia. Both tarsus I and II with solenidion in dorsolateral position.

Copidognathus brevirostris K. Viets, 1927

Copidognathus brevirostris K. Viets, 1927a: 142-143, figs. 77-80.

Copidognathus brevirostris, Green and MacQuitty 1987: 78, 79, fig. 28A-D.

Short description. Length of adults 300 $350 \mu \mathrm{m}$. Body short, width 0.7 times the length. Dorsal plates reticulated. AD with small frontal knob. Ocular plates hardly reaching the level of insertions of legs III. PD with four pairs of faintly raised costae; costae with foveae including 6-10 canaliculi. Opposing margins of AE and GA concave and convex, respectively. In males; perigenital setae arranged in a wide ring, anteriormost pgs almost reaching to anterior margin of GA. Gnathosoma and rostrum short. Rostrum hardly reaching the level of seta on P-2. Tectum with a small, short median process. Length of telofemur I 1.3-1.4 times the height. Tarsus III with four dorsal setae, the two basal ones close together; tarsus IV with three dorsal setae. Claws with pectines.

Norwegian records. Kristiansand (Artsdatabanken 2019); Bergen (Herdla, Paddeholet, low water edge, from Ascophyllum sp. (Phaeophyta)) (K. Viets 1927a, 1928a).

Further records. Along north-eastern Atlantic coast, including the North Sea and the Baltic, from Denmark, France, Germany, the Netherlands, southern Spain (Cadiz), Sweden and the United Kingdom (K. Viets 1956; Bartsch 1976c, 2015a; Green and MacQuitty 1987; Bartsch and Smit 2006).

Biology. Most records of Copidognathus brevirostris are from sheltered, often slightly muddy areas. Substrata inhabited are salt marshes (Puccinellietum), algae (Fucus sp., Ascophyllum sp.) in sheltered bays. Records are from the lower tidal and shallow subtidal zone and from about 10-31 S\%.

Remarks. Compared to other northern Atlantic Copidognathus species, the ornamentation of the dorsal plates of C. brevirostris is weakly developed, the ventral plates are wide, especially the $\mathrm{AE}$, the opposing margins of AE and GA are concave and convex, respectively, not truncate or arched.
Copidognathus brifacius Bartsch, 1989

Copidognathus brifacius Bartsch, 1989a: 320-324, figs. 1-8, 10-14.

Short description. Length of adults 447 $531 \mu \mathrm{m}(531 \mu \mathrm{m}$ is the length of the Norwegian record). Dorsal plates with distinctly demarcated areolae with rosette pores; each rosette pore with fovea surrounded by $5-10$ canaliculi. AD with three such areolae, pair of posterior pair circular in outline. PD with four porose costae, the median pair extending to ovate anterior margin of PD. Ventral plates reticulated, polygons with canaliculi. Rostrum extending anteriad to, rarely slightly beyond the level of seta on P-2. Tectum truncate. Length of telofemur I 2.0 times the height. Each of the three ventral setae on tibia I arising from a small setigerous process; two of the three ventral setae bipectinate, one smooth. Tarsus III with four, tarsus IV with three dorsal setae. Pectines of claws with numerous delicate tines.

Norwegian records. Bergen (Tellnes pier-coll. H. Ringvold). A Copidognathus protonymph recorded from Tromsö (Bartsch 1978a), from the northern part of Grindöy, proved to be a C. brifacius.

Further records: North Sea: Germany, Sweden (Skagerrak), the United Kingdom (England, Robin Hood Bay - coll. C. Poizat; unpublished record); the Baltic: Germany (Bartsch 1989a, 1991a).

Biology. Inhabiting subtidal sandy deposits and their epifauna and flora. Records are from 5 to $55 \mathrm{~m}$ depth.

Copidognathus brifacius is one of the hosts of the suctorian Praethecacineta halacari (Schulz, 1933) which is commonly found on halacarids (Schulz 1933a; Chatterjee et al. 2018). The protonymph from Tromsö proved to be infested, also C. brifacius collected in the Skagerrak area (Bartsch 1989a, Dovgal et al. 2009 Chatterjee et al. 2018) and individuals from the Baltic (Stolper Bank; unpublished record).

Remarks. Very similar to C. fabricii (Lohmann, 1889). The two species are of almost the same size, their plates have similar porose areolae and the ventral setae on tibia I arise from small setigerous processes. Distinguishing characters are mentioned at the end of the presentation of C. fabricii.

Copidognathus fabricii (Lohmann, 1889)

Halacarus fabricii Lohmann, 1889: 347-350, pl. 6, figs. 1, 4, 9, 21, 22, 38, pl. 7, figs. 74, 75, 81, 82, 84, 85, pl. 8, 95, 96-98, 100.

Copidognathus fabriciusi, K. Viets 1927b: 26, 27, figs. 2, 62-65, 91A, B, 92, 105, 106. 
Copidognathus fabricii, K. Viets 1936: 552, fig. 647a-c; Green and MacQuitty 1987: 82, 83, fig. 28A-D; Bartsch 1989a: 323-324, figs. 15-22.

Short description. Length $430-550 \mu \mathrm{m}$. Dorsal plates with slightly raised areolae with foveae at the surface and delicate canaliculi in deeper integumental layers. AD with three such areolae. PD with four areolae in form of costae; these generally two pores wide and not reaching to anterior margin of PD. PD oviform. Parts of ventral plates porose, surface reticulated; porosity absent within transverse area in anterior part of female and male GA. Rostrum extending anteriad just beyond level of seta on P-2. Tectum truncate. Length of telofemur I 2.0-2.2 times the height. On tibia I one of three ventral setae smooth, two bipectinate; each one of setae arising from a small setigerous process. Both tarsus III and IV with four dorsal setae and each basal seta removed from following apical setae. Pectines of claws with about 10 coarse tines.

Norwegian records. Kristiansand (Artsdatabanken 2019; Bergen (Turöy, Osund/Kvernepollen, Herdla shoreline, Hatte Sund)) (K. Viets 1928a).

Further records. North-eastern Atlantic, from the Cape Verde Islands to Iceland, from North Sea, the Baltic and the Mediterranean (K. Viets 1956; Motaş 1961).

An individual similar to Copidognathus fabricii had been extracted from sandy deposits in $5 \mathrm{~m}$ depth, Mudderbugten, Nuuk, Diskö, Greenlandcoll. R.M. Kristensen; unpublished record.

Biology. Inhabitant of lower tidal and subtidal substrata, namely, sandy deposits, algae and colonial organisms.

Remarks. Copidognathus fabricii is in size as well as in the outline and ornamentation of the plates very similar to C. brifacius. Distinguishing characters are: in C. brifacius the pectines on the claws bear numerous delicate tines and tarsus IV has three dorsal setae.

Copidognathus fabricii is often infested by the suctorian Thecacineta calix (Schröder 1907) (Bartsch 1989a; Dovgal et al. 2009).

Copidognathus latus K. Viets, 1927

Copidognathus latus K. Viets, 1927a: 140-142, figs. 74-76a-c.

Short description. Length $505 \mu \mathrm{m}$. Dorsal plates with slightly raised porose areolae. AD with three such areolae, PD with four longitudinal areolae (costae), medial costae in anterior part about two rosette pores wide, in posterior part three to four pores wide. Medial costae extending to anterior margin of $\mathrm{PD}$. $\mathrm{AD}$ slightly protruding. $\mathrm{OC}$ hardly reaching the level of insertions of legs III. Outline of PD ovate. Rostrum longer than basal part of gnathosoma and slightly extending beyond apical end of P-2. Legs slender. Telofemur I 2.5 times longer than high. Tibiae I and II with three ventral bristles, on tibia I one of bristles smooth, the other two slender (no pectination mentioned in the description), on tibia II one seta smooth, two faintly pectinate. Pectines of claws with delicate tines.

Norwegian record. Bergen (Rylands Sund) (K. Viets 1927a, 1928a).

Further records. Unproven records are from Denmark (Hagerman 1966) and Russia (White Sea) (Sokolov 1952; Krivolutsky and Antsiferova 2008).

Biology. The Norwegian record is from a depth of $20 \mathrm{~m}$, from sediment inhabited by sea cucumbers (Cucumaria sp.) and brown algae (Desmarestia sp.).

Remarks. Unfortunately in the type material (slide-mounted in glycerine jelly and stored in the Zoological Museum, Hamburg, CENAK) the black sealing agent has penetrated into the mounting medium, masking large parts of the mite.

Copidognathus latus shows an overall similarity to C. brifacius and C. fabricii but in the two last mentioned species the ventral setae of tibiae I arise from small setigerous processes, such processes are not mentioned in the description of C. latus. Moreover, in C. brifacius and C. fabricii the rostrum and telofemora III and IV are somewhat shorter than in C. latus. New material from the type locality may allow a reliable description.

\section{Copidognathus oculatus (Hodge, 1863)}

Halacarus oculatus Hodge, 1863:300-301, pl. 16, fig. 8.

Copidognathus oculatus, Bartsch 1977a: 2-4, figs. 1-11; Green and MacQuitty 1987: 96, 97, fig. $37 \mathrm{~A}-\mathrm{E}$.

Short description. Length of idiosoma 270 $322 \mu \mathrm{m}$. Colour of integument slightly and uniformly brown. Porose areolae of dorsal plates with rosette pores. Middle of $\mathrm{AD}$ with a transverse, porose areola. Pair of costae on PD about three rosette pores wide. Anterior margin of AD slightly tricuspid. OC elongate, its posterior tail-like part distinctly extending beyond insertion of leg III. Opposing margins of ventral plates AE and GA truncate. Male GA with papilla posterior to $\mathrm{GO}$ and perigenital setae arranged in a dense ring around GO. Rostrum not 
reaching to end of P-2. Tectum with triangular process. Telofemur I short, length:height ratio 1.4-1.5:1. Tarsus III with four dorsal setae, the basal ones distinctly separated; tarsus IV with three dorsal setae. Claws with distinct tines.

Norwegian records. Kristiansand (Artsdatabanken 2019); Bergen (Bogneströmmen, $25 \mathrm{~m}$, and Osund/Kvernepollen, low water edge) (K. Viets 1928a).

Further records. Widespread in the northeastern Atlantic, from Norway (Bergen) to northern Spain (the Bay of Santander), the Mediterranean (France, Italy) (K. Viets 1956; Bartsch 1985a; Green and MacQuitty 1987; Somerfield 1991; Riesgo et al. 2010), North Sea and the Baltic, in the latter basin as far as to Estonia (Järvekülg 1965). The identity of records from the Black Sea is in need of verification (cf. Bartsch 2001b). Durucan (2019a) mentioned C. oculatus from the Turkish Mediterranean coast, but the characters presented in the description and illustrations (Durucan 2019a: 200, fig. 10) do not agree with that nowadays accepted as valid for $C$. oculatus. The specimens studied by Durucan are smaller (212-237 $\mu \mathrm{m}$ long), fig. 10A does not show the large ovate area on the $\mathrm{AD}$, neither the unusual width of the porose costae on the PD; telofemur I (fig. 10G) seems to be slenderer. Unfortunately, the posterior part of the male GA (fig. 10C) is not illustrated.

Biology. Most records are from subtidal habitats, from the surface of sandy deposits, amongst hapteres and algal turfs (Bartsch 1979a and personal observations). There are no records from low saline brackish water.

Remarks. Another species, namely $C$. latisetus, known from the North Atlantic, shares with C. oculatus the characters such as: middle of $\mathrm{AD}$ with a transverse, porose areola, OC with posterior tail-like part extending beyond level of insertion of leg III, male GA with papilla posterior to $\mathrm{GO}$ and perigenital setae arranged in a dense ring around $\mathrm{GO}$, and tectum with triangular process. Differences between these two species are: $C$. latisetus is smaller $(248-285 \mu \mathrm{m})$, slenderer, the median transverse areola on the AD is smaller, the rostrum longer, it reaches to the end of P-2, and the telofemora I are slenderer (height:length 1.7-1.9:1) than in C. oculatus.

Copidognathus reticulatus (Trouessart, 1893)

Halacarus reticulatus Trouessart, 1893: 262, 263, fig. 30A-C; 1894b: 197-199, fig. 3A-C.
Copidognathus reticulatus, Green and MacQuitty 1987: 100, 101, fig. 39A-D.

Short description. Length $275-421 \mu \mathrm{m}$. Dorsal plates reticulated. AD slender, its anterior margin with small triangular process; plate with slightly raised gable-like or arched area, posterior 'legs' of gable two polygons wide; walls of polygons slightly wider than of those outside gable-like area. OC short, length:width $1.8: 1$; reaching posteriad to the level of insertion of leg III. PD with pair of medial and pair of delicate lateral costae. Costae recognizable because of their wider walls of polygons. Pair of ds- 2 in striated integument between $\mathrm{AD}$ and $\mathrm{OC}$. Major parts of ventral plates faintly punctate, marginal parts reticulate. Opposing margins of $\mathrm{AE}$ and GA truncate. Ovipositor extending beyond GO by a length equalling 0.6 times length of GO. Males with 10-12 pairs of pgs rather closely arranged around GO. Rostrum reaching to seta on P-2. Distal half of telofemur I with small ventral lamella. Telofemora, genua and tibiae with short articular membranes. Length:height ratio of telofemur I 2.3:1, its lateral flank reticulated. Tibiae I and II ventrally each with one smooth and two bipectinate setae, on tibia II the basal one of bipectinate setae almost level with smooth ventral seta, hence bipectinated setae situated close together. Tarsus III with four dorsal setae; basal seta distinctly removed from dorsal fossary seta. Tarsus IV with three to four dorsal setae; several individuals with unilateral differences in the number of setae. Pectines of claws with numerous delicate tines.

Norwegian records. Kristiansand (Artsdatabanken 2019); Tromsö (Grindöy); Finmark (Gamvik); Svalbard (Longyearbyen, $78^{\circ} 13^{\prime} \mathrm{N}, 15^{\circ} 40^{\prime} \mathrm{E}$ and Sorgfjord-Baie Treurenberg, $79^{\circ} 58^{\prime} \mathrm{E}, 16^{\circ} 52^{\prime} \mathrm{E}$, 22 m depth) (Trouessart 1902; Bartsch 1978a).

Further records. Northern Atlantic: Greenland, northern Iceland, Russia (the White Sea), Spain, the United Kingdom (the Isle of Man, Northern Ireland) (Trouessart 1902; Green and MacQuitty 1987; Somerfield 1988; Bartsch 2009; Krivolutsky and Antsiferova 2008; Riesgo et al. 2010). If the species C. gorbunovi Sokolov, 1946 turns out to be a junior synonym of $C$. reticulatus, the record from Franz Josef Land (Sokolov 1946) will have to be added to this list.

Biology. Most records are from just below the lower tidal fringe to about a $50 \mathrm{~m}$ depth, here the mites had been extracted from brown and red algae (Fucus sp., Laminaria sp., corallines) and from tunicates. Marine. 
Remarks. Four species from the northern Atlantic are similar in general shape and have a gablelike raised area on the AD, namely, Copidognathus gorbunovi, C. loricifer André, 1946, C. poucheti Trouessart, 1893, and C. reticulatus. The two costae on the PD of C. poucheti are posteriorly fused, U-shaped (Trouessart 1893), in the other just mentioned species the costae are separated throughout their length. In $C$. loricifer, the gnathosoma has three pairs of maxillary setae (André 1946) and the basal one of the three ventral setae on tibia $I$ is spiniform; the other three species have two pairs of maxillary setae and the basal ventral seta on tibia I is bristle-like (bipectinate). Copidognathus gorbunovi and C. reticulatus are similar in characters such as outline and ornamentation of the plates, shape of the gnathosoma and legs, and in both species the distal half of telofemur I has a small ventral lamella. Further studies may prove $C$. gorbunovi to be a junior synonym of $C$. reticulatus.

Copidognathus rhodostigma (Gosse, 1855)

Halacarus rhodostigma Gosse, 1855a: 27, pl. 3, figs. 1-5.

Halacarus (Copidognathus) rhodostigma, Trouessart 1894a: 172.

Copidognathus rhodostigma, K. Viets 1927a:

136; Bartsch 1979b: 221-223, figs. 15-23; Green and MacQuitty 1987: 102, fig. 40A-D.

Short description. Length of adults 318$379 \mu \mathrm{m}$. AD with slightly raised porose areolae; anteromedian one and pair of ovate ones more or less contiguous; fourth transverse area along posterior margin of plate. PD with four pairs of slightly raised costae; two costae of each side often anteriorly fused. Ventral plates marginally with porose foveae, towards median part only a few small pores present. Opposing margins of AE and GA truncate. Rostrum shorter than gnathosomal base, not reaching to the level of seta on P-2, only to middle of P-2. Telofemora I and II with porose foveae. Telofemur I 1.7 times longer than high; its ventral margin with pair of costae; these rarely straight, generally slightly bulging. Tibiae I and II each with two bipectinate and one slender, smooth seta; tibia III and IV each with one bipectinate and one slender, smooth seta. Tarsus IV with three dorsal setae. Pectines of claws on tarsi III to IV with numerous delicate tines.

Norwegian records. Bergen (Tellnes Piercoll. H. Ringvold), from $15 \mathrm{~m}$ depth. New record for Norway.
Further records. Along the coasts of the Northeastern Atlantic: Eire, France, Denmark, the United Kingdom (England, Northern Ireland, Scotland, Wales), Germany, Spain, Sweden; the Mediterranean (K. Viets 1956; Bartsch 1979a, 1985a, b, 1991a; Green and MacQuitty 1987; Somerfield 1988, 1991; Riesgo et al. 2010; Carriglio 2010). Black Sea records are in need of verification (Bartsch 2001b).

Biology. Inhabitant of the surface layer of sandy deposits, with or without algae. Commonly found in subtidal areas, from just below the low water edge to more than $50 \mathrm{~m}$ depth. Rarely extracted from tidal beaches (Bartsch 1979a, 1985a, b).

Remarks. Copidognathus rhodostigma has a very short rostrum, it reaches to the middle of P-2; in most of the other Copidognathus species the rostrum extends beyond this line.

Copidognathus richardi (Trouessart, 1902)

Halacarus richardi Trouessart, 1902: 69, 70.

Copidognathus richardi, Bartsch 1983a: 285-288, figs. 1-9; 1991b: 1347-1348, figs. 16 and 17.

Short description. Length 550-570 $\mu \mathrm{m}$. Dorsal plates with raised areolae, surface of these areolae with rosette pores, i.e. foveae at the surface and few delicate canaliculi in deeper layers. AD short, almost rectangular, with rounded anterior and dumbbell-like median areola. PD with two pairs of costae. OC with two corneae. Ventral plates with demarcated areolae with rosette pores. Females with anterior pair of the three pairs of pgs close to anterior margin of GA. Male GA with 47 perigenital setae densely arranged around GO. In female interval between anterior margin of GO and that of GA equalling length of $\mathrm{GO}$, in males more than length of GO. Rostrum extending just beyond tip of P-2. Gnathosoma of males with three pairs of maxillary setae, two pairs on gnathosomal base, one pair on rostrum. Telofemur I slender, its length:height ratio 2.4:1. Three ventral setae of tibia I slender, on tibia II one seta widened and bipectinate, two slender, on tibiae III and IV both ventral setae slender. Each of medial and lateral articular membranes of tibiae with delicate lamellar dent. Tarsi III and IV with three dorsal setae. All claws with pectines.

Norwegian record. Southeast of Svalbard, near Hopen Island, $76^{\circ} 30^{\prime} \mathrm{N}, 25^{\circ} 27^{\prime} \mathrm{E}, 48 \mathrm{~m}$, pebbles and shell fragments, and north of Svalbard, $80^{\circ} 01^{\prime} \mathrm{N}$, $10^{\circ} 51^{\prime} \mathrm{E}, 430 \mathrm{~m}$, muddy sand (Trouessart 1902).

Further records. Azores, from a depth of 599 m (Trouessart 1902). 
Biology. Most records are from tidal and shallow subtidal zones.

Remarks. Copidognathus richardi is similar to C. granulatus (Hodge, 1863). According to Bartsch (1991b) there is a difference in the length of the idiosoma, namely 550-570 $\mu \mathrm{m}$ (C. richardi) vs. $425-460 \mu \mathrm{m}(C$. granulatus $)$ and the shape of the ventral setae on the tibiae, namely on tibia I all three setae smooth and similar in length vs. one of ventromedial setae short and bipectinate. New material from the type localities of the two species is needed for a detailed examination of morphological characters, this may either give more reliable distinguishing characters or prove $C$. richardi to be a junior synonym of $C$. granulatus.

\section{Genus Halacarellus K. Viets, 1927}

Diagnosis. Dorsal plates lack conspicuous porose areolae. P-2 with one distodorsal seta. Third palpal segment with medial spur or short seta. Genu I shorter than adjacent segment. Tarsus I with one, rarely two ventral spurs or setae. Tarsi I and II each with three dorsal setae; solenidion on tarsus I in dorsolateral, on tarsus II in dorsomedial position.

Halacarellus balticus (Lohmann, 1889)

Halacarus balticus Lohmann, 1889: 341, 342, pl. 6, fig. 40, pl. 8, figs. 108, 119, 120, 123.

Halacarellus balticus, K. Viets 1927a: 120.

Thalassarachna baltica, Green and MacQuitty 1987: 118, 119, figs. 47A-E.

Short description. Length of females 553$800 \mu \mathrm{m}$, of males 575-715 $\mu \mathrm{m}$. Major parts of dorsal plates with foveate or reticulate ornamentation, raised areas punctate, these present on arched median part of AD and on pair of costae of PD. Dorsal plates of females and males similar in outline. Anterior and posterior margin of $\mathrm{AD}$ truncate, anterior margin of PD ovate. Length of PD less than twice that of AD. Male GA larger than female GA. Distance between GO and anterior margin of GA in females about half length of GO; in males that distance somewhat more than length of GO. Length of gnathosoma about one-third of that of idiosoma. Rostrum shorter than gnathosomal base. Telofemur I with one ventral seta. Tibia I generally with eight ventral setae, rarely with four (cf. Bartsch 1972: fig. 22F), six, seven or nine setae. Two or three of these ventral setae short, spur-like, the other bristle-like. Claws with J-shaped pectines.

Norwegian records. Stavanger (Lysebotncoll. H. Ringvold); Bergen, low water edge: (Røyr-
vik/Tørvikbygda, Håkonshella, Nordheimsund, Bjelkarvågen, Nordnes, Lindås - coll. H. Ringvold); Turöy, Kvernepollen, Herdla/Paddeholet, Sjatien ved Kalsöy, Hatte Sund, Stensund; bottom samples, 20 m depth: Rylands Sund and Rosland Vaag (K. Viets 1928a).

Further records. North-western Atlantic: Greenland (Godhavn), Canada (New Brunswick), the United States (from Massachusetts to New York); North-eastern Atlantic: Denmark, Eire (east, south, west coast), France, Germany, Russia (the Barents Sea and the White Sea), Spain, Sweden (Öresund), the United Kingdom (England, Outer Hebrides, Scotland, Wales); the Baltic: Denmark, Estonia, Finland, Germany, Latvia, Poland (Lohmann 1889; Newell 1947; K. Viets 1956; BazanStrzlecka 1972; Bartsch 1972, 1982; Jarvekjul 1979; Pugh and King 1985; Green and MacQuitty 1987; Riesgo et al. 2010; Krivolutsky and Antsiferova 2008).

Biology. Halacarellus balticus lives in various habitats and sea levels. The species has been taken from middle, lower and subtidal colonies of bryozoans, hydrozoans, barnacles and bivalves, from salt marshes and green and brown algae which held (almost) no bryozoans or hydrozoans, from areas exposed to swell but also from sheltered ones (Bartsch 1972, 1978c, 1982). Halacarellus balticus has been found in a salinity range from about 3 to $31 \%$. In general, it is carnivorous, though rarely, it also feeds on algae (Bartsch 1974a).

A juvenile specimen was infested with the suctorian Thecacineta calix.

Remarks. In contrast to the other Halacarellus species mentioned from Norway (cf. below), the $\mathrm{PD}$ of $H$. balticus is rather short, its length is less than twice that of AD (vs. being at least or distinctly more than twice that length).

Halacarellus petiti Angelier, 1950, as yet not found in Norway, is slightly smaller than $H$. balticus but the two species are similar in the general shape of the idiosoma, plates and legs. Distinguishing characters are given in Bartsch (1976b) and Green and MacQuitty (1987). According to present data (Angelier 1950; Bartsch 1979a), H. petiti has been found in constantly low saline habitats (2$16 \%$ ) but also in ones with enormously fluctuating salinity (1\%o at low, 30\%o at high tide).

Halacarellus capuzinus (Lohmann, 1893)

Halacarus capuzinus Lohmann, 1893a: 199201, figs. 1-5. 
Halacarellus capuzinus, Schulz 1933b: 98, 99, figs. 4, 5; Bartsch 1972: 205-209, figs. 25A-L. Halacarellus (Thalassarachna) capuzinus, Newell 1947: 118-123, figs. 179-191.

Thalassarachna capuzina, Green and MacQuitty 1987: 122-123, figs. 49A-D.

Short description. Length $250-367 \mu \mathrm{m}$. AD with short frontal process. Dorsum with four plates and three pairs of small sclerites bearing dorsal setae. Gnathosoma about 1.3-1.5 times longer than wide. Rostrum short, extending to but not beyond level of seta on P-2. Tibia I ventrally with two spur-like and three slender smooth setae, tibiae II to IV ventrally each with one slender and two coarsely bipectinate setae.

Norwegian records. Bergen (Grønevika, Sandholna by swing - coll. H. Ringvold); Tromsö (Kvalöy, southern and north-eastern edges of Grindöy), sandy deposits on slope of beach (Schmidt 1972; Bartsch and Schmidt 1979).

Further records. Western North Atlantic: Canada (New Brunswick), the United States (from Massachusetts to Connecticut); Eastern North Atlantic: Eire, France, the United Kingdom (Northern Ireland, Scotland, Wales); the North Sea, the Baltic (as far as Poland and northern Sweden) (Bartsch 2017).

Biology. Inhabitant of sandy or turfy deposits, also extracted from brown algae (Fucus). Salinity ranges from 1 to about 30\%. An individual (female) from Sandholna was inhabited by a suctorian (Thecacineta sp.).

Remarks. Halacarellus capuzinus belongs to the capuzinus group (cf. Bartsch 1997a, 2017). Distinguishing characters of the Norwegian species are given in Remarks added to Halacarellus subcrispus.

Halacarellus floridearum (Lohmann, 1889)

Halacarus floridearum Lohmann, 1889: 340-

341, pl. 6, fig. 41, pl. 8, figs. 111, 112, 114-116.

Halacarellus floridearum, Bartsch 2017: 74 76, 79-80, figs. 2A-G, 3A-D.

Halacarus (Halacarellus) bergensis K. Viets, 1927a: 219-131, figs. 61-66.

Short description. Length 402-555 $\mu \mathrm{m}$. Dorsum with $A D$, pair of $O C$ and $P D$ but without small dorsal sclerites. Anterior margin of AD truncate. Gnathosoma 1.5-1.7 times longer than wide. Legs slender, their length less than that of idiosoma. Tibia I with (5-)6(-7) setae, two basal setae spurlike. Tibiae II to IV ventrally with one smooth seta and 2, 3, 2 bipectinate setae, respectively.
Norwegian records. Bergen (Osund/Kvernepollen, Sjatien, Rosland Vaag, from low water edge) (K. Viets 1927a, 1928a); Tromsö (Bartsch 1978a; Bartsch and Schmidt 1979); Finmark (Gamvik) (Bartsch 2017).

Further records. Spread in the western and eastern North Atlantic and the White Sea. North Atlantic records are from Greenland, Norway and Russia, North Sea records from the Netherlands, and the Baltic ones come from Germany, Poland, Estonia (cf. Bartsch 2017). A record from the Mediterranean (Carriglio 2010) is in need of verification.

Biology. Found amongst algae (Enteromorpha, Fucus, Ascophyllum, Laminaria with bryozoans), vascular plants (Zostera) and sediments which were extracted from the lower tidal to subtidal $(160 \mathrm{~m})$ zone (K. Viets 1928a; Bartsch and Schmidt 1979). Also found in the mantle cavity of bivalves (Krapivin 2012).

Remarks. This is a species of the capuzinus group; distinguishing characters of this group are discussed within the Remarks added to Halacarellus subcrispus.

Halacarellus procerus K. Viets, 1927

Halacarus (Halacarellus) procerus K. Viets, 1927a: 127-129, figs. 57-60.

Halacarellus procerus, Bartsch 1976b: 103, figs. 10-23; 2017: 80-81, fig. 3F.

Thalassarachna procera, Green and MacQuitty 1987: 126-127, fig. 51A-D.

Short description. Length (350?) 372$496 \mu \mathrm{m}$. Dorsum with AD, pair of OC, PD and three pairs of minute sclerites, each sclerite with one of dorsal setae ds-2, ds-3 and ds-4. Length of gnathosoma 1.4-1.6 times the width. Rostrum extending to the level of seta on P-2. Tibia I with 8 ventral setae, tibiae II to IV with three setae each; 2, 2, 2 of these setae bipectinate, 1, 1, 1 setae smooth and slender. Tarsus I of $H$. procerus with two spur-like ventral setae.

Norwegian record. Tromsö (Kvalöy, southwestern edge of Grindöy) (Bartsch and Schmidt 1979).

Further records. Widespread in the North Atlantic. Records from the north-western Atlantic are from the United States (Massachusetts), those from the north-eastern Atlantic, including the North Sea, the Baltic, and the Black Sea, are from the Azores, Denmark, Eire (Dublin, West Cork), France (English Channel), Germany (North Sea and the Baltic), Romania, Spain (La Coruňa), Sweden (Öresund?), and the United Kingdom (Northern Ireland, Strangford Narrows) (Bartsch 1989a, 2017). 
Biology. Inhabitant of tidal and shallow subtidal sediment. Most abundant in the middle and lower slope of a beach. Salinity ranges from 7 to $32 \%$.

Remarks. Unique in Halacarellus procerus are the two spur-like ventral setae on tarsus I, all other northern Halacarellus species have a single spur-like seta.

Halacarellus procerus belongs to the capuzinus group; aditional distinguishing characters are added to the Remarks after the description of $H$. subcrispus.

Halacarellus subcrispus Bartsch, 1978

Halacarellus subcrispus Bartsch, 1978a: 1014, figs. 10-24, Bartsch 2017: 82.

Short description. Length 407-478 $\mu \mathrm{m}$. Idiosoma slender. Surface of dorsal plates almost smooth. Setae ds-2, ds-3 and ds-4 arising from small sclerites. Gnathosoma slender, rostrum not reaching to the level of end of P-2. Tibia I ventrally with seven setae, two of these spur-like, five bristle-like. Tibiae II to IV each with three ventral setae, two bipectinate, one slightly longer and slender.

Norwegian records. Tromsö (Kvalöy, Grindöy) and Svalbard (Longyearbyen, Ny Ålesund) (Bartsch 1978a; Bartsch and Schmidt 1979).

Further records. Western Greenland nearshore in almost fresh water (Bartsch 2017).

Biology. Extracted from tidal and shallow water sandy deposits, from lower to mean high water level (Bartsch and Schmidt 1979). Supposed salinity range is from almost fresh to about $32 \%$.

Remarks. Halacarellus capuzinus, H. floridearum, $H$. procerus and $H$. subcrispus belong to the H. capuzinus group (Bartsch 2017). Halacarellus capuzinus is the smallest one, $H$. floridearum lacks the pairs of small dorsal sclerites while $H$. procerus and $H$. subcrispus both have these three pairs of sclerites. Another distinguishing character is the number of ventral setae on tibia I, eight in $H$. procerus but seven in H. subcrispus.

Halacarellus subterraneus Schulz, 1933

Halacarellus subterraneus Schulz, 1933b: 100, 101, figs. 7-10; Bartsch 1998: 168-170, figs. 107-117.

Halacarus (Thalassarachna) subterraneus, Newell 1947: 112-118, figs. 168-178.

Thalassarachna subterranea, Green and MacQuitty 1987: 132, 133, fig. 54A-D.

Short description. Length $425-570 \mu \mathrm{m}$. Dorsal plates with slightly foveate ornamentation. Anterior margin of AD as well as opposing margins of $\mathrm{AD}$ and PD truncate. PD almost three times longer than $\mathrm{AD}$. Each $\mathrm{OC}$ with two gland pores in lateral margin. Pair of elongate sclerites between PD and PE. Rostrum with both pairs of maxillary setae and extending to about end of P-2. Telofemur I with three stout ventral spines, these spines increasing in length from basal to apical, from 25 to almost $40 \mu \mathrm{m}$. Tibiae I to IV with 8, 6, 4, 4 ventral setae. Claws II to IV pectinated.

Norwegian records. Bergen (Bjelkarvågen, end of road - coll. H. Ringvold); Tromsö (Kvalöy, Grindöy); Svalbard (Bartsch and Schmidt 1979).

Further records. Widespread in the North Atlantic. Western Atlantic records are from the United States (Rhode Island and Connecticut); eastern Atlantic ones are from Eire, France, Germany, the United Kingdom (England, Wales), Russia (the White Sea), and Sweden), further records are from the Baltic (Germany, Sweden) and the Black Sea (Bulgaria, Ukraine) (Schulz 1933b; Newell 1947; Dahl and Wieser 1955; Bilio 1966; Bartsch 1972, 1979a, c, 1982, 1998; Pugh and King 1985; Green and MacQuitty 1987; Somerfield 1991; Krivolutsky and Antsiferova 2008).

Biology. Inhabitant of sandy deposits in the mid- and upper tidal area of beaches, also commonly found in salt marshes. Several records are from almost fresh nearshore groundwater, from just above the groundwater level (Bartsch 1972, 1974a). In beaches from near Tromsö (Grindöy), it proved to be the dominant halacarid species (Bartsch and Schmidt 1979). Collected within a salinity range from 1-30\%o (Bilio 1966; Brinck et al. 1955; Bartsch 1972, 1998; Bartsch and Schmidt 1979).

Remarks. Adults of Halacarellus subterraneus are characterized by the three stout ventral spines on telofemur I. Another two Halacarellus species are known to have three stout spines, namely, H. arenarius Bartsch, 1979 and H. phreaticus Petrova, 1972. Halacarellus arenarius is a species of the north-western Atlantic and H. phreaticus is only known from the Mediterranean and the Black Sea freshwater zones, even as far as $120 \mathrm{~km}$ away from the sea shore (Petrova 1972; Bartsch 1979c; Morselli and Mari 1986; Galassi et al. 2009).

\section{Genus Halacarus Gosse, 1855}

Diagnosis. AD present, OC and PD distinct, reduced to small platelets or even absent. Plates smooth or faintly reticulated and with prominent costae or porose areolae. Majority of species with five pairs of gland pores. Second palpal segment 
with two setae in its posterior half. Third palpal segment with medial spur. Tibia, genu and telofemur I almost equal in length. Tibia I with four ventral spines, these tapering or with a blunt tip. Solenidion and famulus on tarsus I generally rather equal in length. Solenidion on tarsus II in dorsomedial position.

Halacarus bisulcus K. Viets. 1927

Halacarus bisulcus K. Viets, 1927a: 118-120, figs. 45-47.

Halacarus bisulcus, Weinstein 1961: 208-212, figs. I A-F, II P1-P4, C; Bartsch 1980: 39, figs. 16-20; Green and MacQuitty 1987: 112-113, fig. 45 A-D.

Short description. Length $435-537 \mu \mathrm{m}$. Integument on plates and legs with delicate epicuticular striae. AD with frontal spine. OC very small, posteriad not extending to glp-3. Female PD shorter than male PD; in both, PD anteriad not reaching the level of glp-4. Female GA with two pairs of pgs and a pair of bean-shaped areas with raised cerotegument. Male with about 35 pgs closely arranged around $\mathrm{GO}$ and three to four pairs of outlying pgs. Telofemur I with one slender, tapering and one short, bluntly ending spine. Genu and tibia I with one and two pairs of smooth, tapering spines, respectively. Tarsus I with two bristlelike ventral setae, tarsi III and IV with pair of pas but no further ventral setae.

Norwegian records. Kristiansand (Artsdatabanken 2019); Bergen (Herdla Sund, sandy deposits rich in shell, $10 \mathrm{~m}$ depth) (K. Viets 1927a, 1928a).

Further records. North-eastern Atlantic and North Sea: Eire, Faeroe Islands, France, Germany, Iceland, Sweden, the United Kingdom (England, Northern Ireland). The Mediterranean: France, Italy (Weinstein 1961; Motaş 1961; Morselli and Mari 1985; Bartsch 1979a, 1991a; Green and MacQuitty 1987; Somerfield 1991; Carriglio 2000). A record from the Mediterranean coast of Turkey (Durucan 2019b) seems to be not one of H. bisulcus. The individuals are smaller (females 349$350 \mu \mathrm{m})$ than elsewhere documented and the PD includes and extends anteriad beyond the glp-4 (Durucan 2019b: fig. 5A) whereas in H. bisulcus the glp-4 are in the striated integument and the PD does not reach that far. The $\mathrm{OC}$ of $H$. bisulcus have no cornea. Durucan (2019b: 273, lines 3 and 16) mentioned both character states, namely OC with and without cornea. The Halacarus species described by Durucan (2019b) may be a H. subtilis K. Viets, 1940.
Biology. Inhabitant of coarse lower tidal and subtidal sediment and Maërl as well as algae and colonial organisms (Weinstein 1961; Bartsch 1980). Present records are from the lower tidal fringe to about a depth of $40 \mathrm{~m}$. There are no records from brackish water areas $(<28 \mathrm{~S} \%)$.

Remarks. At least three North-eastern Atlantic Halacarus species are expected to inhabit shallow water areas $(<200 \mathrm{~m})$ of the Norwegian Exclusive Economic Zone, namely $H$. bisulcus, $H$. actenos Trouessart, 1889, and H. borealis Trouessart, 1893 (Trouessart 1889a, 1893; K. Viets 1927a), though at present, there are no records of the two last mentioned species. Halacarus actenos has an AD, a pair of small OC, but no PD. OC and PD of $H$. borealis are larger than in $H$. bisulcus, the plates include glp-3 and glp-4. Halacarus borealis is similar to H. ctenopus Gosse, 1855, a species which is expected to be restricted to the western Atlantic (Bartsch 2009).

\section{Genus Isobactrus Newell, 1947}

Diagnosis. Plates with delicate, rather uniform ornamentation. Each OC with two gland pores. Epimeral plates small, EI and EII as well as EIII and EIV partly divided. Epimera I and II widely separated in the midline, not fused to AE. In females, GO within striated integument, not on a distinct genital plate. In males, GO on a distinct genital plate. Gnathosoma short, at ventral aspect almost triangular, at dorsal aspect partly or completely concealed by anterior part of idiosoma. Genua of all legs shorter than telofemora and tibiae. Tibiae I and II with pair of ventral setae, tibiae III and IV with one to two such setae. All tarsi lack ventral setae. Solenidia on both tarsus I and II small, clavate and in dorsolateral position.

Biology. Species of this genus are algivorous. In non-tidal basins they live close to the water line, in areas with a regular tide in the tidal zone. Most, but not all species seem to be restricted to the upper tidal belt exposed to long periods of desiccations. Inhabitants of small green algae (Enteromorpha, Blidingia, Monostroma) and delicate green algal films on macrofauna and -flora.

Isobactrus hartmanni Bartsch, 1972

Isobactrus hartmanni Bartsch, 1972: 193-196, figs. 20A-G, 21A-D.

Isobactrus hartmanni, Bartsch 1975a: 66, figs. 64-67.

Short description. Length of females 310 $445 \mu \mathrm{m}$, of males $290-378 \mu \mathrm{m}$. AD slightly longer 
than wide. Dorsal plates reticulated. Pair of glp-1 distinctly anterior to ds- 1 . Distance between ds- 1 smaller than that between ds-1 and margin of plate. Anterior margin of PD semi-circular. Epimeral plate III without setae but pair of setae present in adjacent striated integument. Tarsi I to IV with 4, 4, 4, 3 dorsal setae; on all tarsi dorsal fossary seta long, extending beyond claws. Claws with about six apical tines.

Norwegian records. Stavanger (Lysebotn, Vikedal camping — coll. H. Ringvold); Bergen (Røyrvik, Nordnes, Eidsvågneset — coll. H. Ringvold); new records for Norway.

Further records. North-western Atlantic: the United States (Rhode Island), North-eastern Atlantic: France; the North Sea and the Baltic: Denmark (Öresund), Germany (Bartsch 1972, 1975a, 1979c).

Biology. The species can be found in rather large numbers amongst brown algae (Ascophyllum sp., Fucus sp. and Pelvetia sp.), green algae and barnacles in the middle and upper tidal area; especially if these substrata are regularly desiccated due to exposure to the sun. Present also in the lower tidal area on pebbles and shells with delicate green algae (Bartsch 1972, 1978c, 1982). Found within a salinity range of about 18 to $31 \%$.

Remarks. With its claws, apically bearing a few tines, I. hartmanni is most similar to I. setosus. Morphological differences are: the AD of I. hartmanni is distinctly longer than wide and the setae generally situated on EIII and IV are within the striated integument whereas in I. setosus the AD is wider than long and EIII and EIV each bear one ventral seta.

If experienced, the two species can be separated at low magnification $(25 \times)$ on the basis of an arched (I. hartmanni) vs. somewhat pointed, triangular (I. setosus) frontal margin of the AD.

Isobactrus levis (K. Viets, 1927)

Rhombognathus levis K. Viets, 1927a: 103105, figs. 19-22.

Isobactrus levis, Newell 1947: 74-77, figs. 71-

73; Bartsch 1975a: 64, 65, figs. 62, 63; Green and MacQuitty 1987: 22, 23, figs. 5A-D.

Short description. Length of females 316$372 \mu \mathrm{m}$, of males $304-310 \mu \mathrm{m}$. AD longer than wide and almost as long as PD. Distance between pair of ds- 1 less than that between ds-1 and lateral margin of AD. Epimeral plates III and IV without ventral setae, these setae in striated integument. Dorsal fossary seta on tarsi I to IV duplicated and long, distinctly extending beyond claws. Tarsal claws smooth.

Norwegian records. Kristiansand (Artsdatabanken 2019); Bergen (Røyrvik - coll. H. Ringvold) and Paddeholet on Herdla (K. Viets 1928a); Svalbard (Chertoprud et al. 2017).

Further records. North-western Atlantic: the United States (Rhode Island, Connecticut) (Bartsch 1982). North-eastern Atlantic, Arctic Ocean, North Sea, and the Baltic: Eire, France (English Channel), Germany (Elbe and Weser estuary), Russia (White Sea, Barents Sea), Sweden (Skagerrak), the United Kingdom (England, Wales) (Sellnick 1949; Green 1956; Bartsch 1972, 1975a; Pugh and King 1985; Somerfield 1988; Krivolutsky and Antsiferova 2008). The Baltic records (Sellnick 1949) are from east and north of Stockholm, from Kalkskär (ca $58^{\circ} 51^{\prime} \mathrm{N}, 17^{\circ} 56^{\prime} \mathrm{E}$ ) and from Tjärven (ca $59^{\circ} 48^{\prime} \mathrm{N}, 19^{\circ} 22^{\prime} \mathrm{E}$ ).

Biology. Extracted from green and brown algae and from barnacles growing in tidal areas. Mostly taken in the upper tidal zone, but rarely in large numbers. Seems to be more common in low than in high saline areas (personal observations). Known to inhabit a salinity range from 3 (Elbe estuary, Brokdorf) to about 30\%.

Remarks. Isobactrus levis is the only Isobactrus species with a duplicated dorsal fossary seta, hence tarsi I to IV bear 5, 5, 5, 4 dorsal setae (solenidia included) instead of 4, 4, 4, 3 setae.

Isobactrus setosus (Lohmann, 1889)

Aletes setosus Lohmann, 1889: 326-328, pl. 6, figs. $16,18,47 \mathrm{a}-\mathrm{c}$, pl. 7 , figs. 79,80 , pl. 9 , fig. $90 \mathrm{a}, \mathrm{b}$.

Isobactrus setosus, Newell 1947: 69-74, figs. 54-70; Bartsch 1975a: 64, figs. 60, 61; 1975b: 195, fig. 4a-c; Green and MacQuitty 1987: 24, 25, figs. 6A-D.

Short description. Length of female 294 $427 \mu \mathrm{m}$. Males not known. AD slightly wider than long; its anterior margin triangular and slightly pointed, posterior margin wide and truncate. Anterior margin of PD arched. Plates representing EIII each with one dorsal and one ventral seta, EIV with one ventral seta. Tarsi I to IV with 4, 4, 4, 3 dorsal setae. Dorsal fossary setae hardly extending beyond claw fossa. Distally widened claws with 8-9 short dents.

Norwegian records. Kristiansand (Artsdatabanken 2019); Stavanger (Jektevika—coll. H. Ringvold); Bergen (Røyrvik, Grønevika, Håkanshella, Lindås- 
coll. H. Ringvold - and Osund, Herdla, Rylands Sund, Roslands Vaag) (K. Viets 1927a, 1928a).

Further records. North-western Atlantic: Canada (Quebec) (Bartsch 1997b); the United States (Massachusetts to New York). North-eastern Atlantic: from Spain to Norway and from the North Sea (Germany, Denmark; the United Kingdom) and the Baltic (as far as the Bothnian Bay, Finland) (K. Viets 1937; Bartsch 1972, 1982; Green and MacQuitty 1987).

Biology. Often found in high numbers in lower tidal areas; in non-tidal basins along the water line on green algae (Monostroma) as well as green algal films on Fucus and barnacles. Documented to inhabit a salinity range of 5 to $31 \%$ (Bartsch 1972).

Adult Isobactrus setosus, in September collected in Bergen (Håkanshella), were inhabited by the suctorian Acineta sp. (A. sulcata Dons, 1927). The one to more than 20 suctorians per mite were primarily fixed to the legs. The loricae, with several interrupted transverse ridges, were laterally compressed, the apical opening narrow. The length of the loricae varied between 35 and $73 \mu \mathrm{m}$, the width between 30 and $42 \mu \mathrm{m}$. The two bundles of tentacles, situated on actinophores, were withdrawn in the loricae. The stalks were somewhat shorter than the loricae.

Most records of $A$. sulcata are from halacarid mites (Dovgal et al. 2008; Chatterjee et al. 2018). The suctorians described by Dons (1927) had been collected on the coast line of Gibostad, and Evenskjer, in the Tjeldsund, both sites in the northern part of Norway.

Remarks. Isobactrus setosus is most similar to I. hartmanni. Distinguishing characters are mentioned above.

Isobactrus ungulatus Bartsch, 1975

Isobactrus ungulatus Bartsch, 1975a: 71, 72, figs. 105-121; Green and MacQuitty 1987: 26, 27, fig. 7A-E.

Short description. Length of females $272-$ $334 \mu \mathrm{m}$, of males $260-319 \mu \mathrm{m}$. AD almost as long as wide, its anterior margin arched. Epimeral plates almost completely separated. EIII with one dorsal and one ventral seta, EIV with one ventral seta. Tarsi I to IV with 4, 4, 4, 3 dorsal setae. Claws apically truncate and widened, this part with 7-11 conspicuous dents.

Norwegian records. Bergen (Golten, Telavåg, Grønevika, Arboretet Sandholna, Hagenes bay,
Håkonshella/Pollen, Peak of Nordnesparken, Lindås/ Leirvåg — coll. H. Ringvold). New record for Norway.

Further records. North-western Atlantic: Eire, France (Bretagne, Gironde), the United Kingdom (England, Northern Ireland, Wales); the Mediterranean (Croatia) (Bartsch 1975a, 1976c; Green and MacQuitty 1987; Somerfield 1988).

Biology. The species has been found on barnacles, green algae and lichens growing in the upper tidal zone.

Remarks. The most obvious character of I. ungulatus is the shape of the claws, namely the apically widened accessory process with up to 11 dents. In the other Isobactrus species the claws are smooth or apically slightly widened but bearing only minute dents.

A few adult Isobactrus ungulatus collected in August and October around Bergen (Golten, Telavåg) were infested with the suctorian Acineta sp. (A. sulcata).

\section{Genus Lohmannella Trouessart, 1901}

Diagnosis. Body generally flattened and rather wide. Surface of dorsal plates almost smooth, reticulated or granulated but not heavily sculptured. Gnathosoma slender, longer than wide, its length from somewhat less than half to slightly more than total length of idiosoma. Four-segmented palps in dorsal position, i.e. distance between paired P-1 generally less than width of P-1 and hence P-1 obscured in ventral aspect. P-2 with two dorsal setae. Third palpal segment with spur-like process (no spur because alveolus lacking). P-4 basally with three setae and medial spur. Genua of all legs shorter than telofemora and tibiae.

\section{Lohmannella falcata (Hodge 1863)}

Leptognathus falcatus Hodge, 1863: 302-303, pl. 16, figs. 6, 7 .

Lohmannella falcata, Fountain 1953: 363-364, fig. 3; Newell 1947: 190, 191, figs. 327-330; Green and MacQuitty 1987: 140, 141, fig. 57A-D.

Short description. Length 298-501 $\mu \mathrm{m}$. AD hexagonal. OC with two corneae. Rostrum slender, longer than gnathosomal base. P-2 slender, its length about five times the diameter of basal part and more than 10 times longer than P-3. Tibia I with six, rarely five bipectinate setae. Tarsus IV with four dorsal setae. Claws with minute accessory process.

Norwegian record. Bergen (Bjelkarvågencoll. H. Ringvold) and Hattesund (K. Viets 1928a). 
Further records. Northwestern Atlantic: Canada (New Brunswick); the United States (Rhode Island). North-eastern Atlantic and the adjacent North Sea, the Baltic and the White Sea: Denmark, Eire, Estonia, Finland, France, Germany, Iceland, Latvia, the Netherlands, Poland, Russia, Spain, Sweden, the United Kingdom (England, Northern Ireland, Scotland, Wales) (K. Viets 1956; Motaş 1961; Źmudziński 1974; Jarvekjul 1979; Green and MacQuitty 1987; Somerfield 1988; Bartsch and Smit 2006; Krivolutsky and Antsiferova 2008; Riesgo et al. 2010). The Mediterranean and the Black Sea: France, Italy, Monaco, Bulgaria, Crimea, Romania, Russia (Caucasian coast), Turkey, Ukraine (K. Viets 1956; Bartsch 2004a; Durucan 2018).

A deep-water record from 2,500-3,000 $\mathrm{m}$ and tentatively called L. falcata (Bartsch 1978b) is no L. falcata (cf. Bartsch 2003b).

Biology. Extracted from various lower tidal and subtidal substrata, often found amongst colonies of hydrozoa. Inhabiting a salinity range from about 10 to $33 \mathrm{~S} \%$. A record mentioned by Svenonius (1949) from Bottenviken (Gulf of Bothnia), the Baltic, Sweden, from the 2.5-3.5 S\%, may be one of Porolohmannella violacea (Kramer, 1879). The latter species has commonly been found in this area (Bartsch 1989b; personal observations) and its general shape is similar to that of L. falcata.

Remarks. This is one of the few Lohmannella species with four dorsal setae on tarsi III and IV. At present, we know two northern Atlantic Lohmannella species with the combination: rostrum slender and four dorsal setae on tarsus III and IV, namely, L. falcata and L. sulensis (mentioned below). The majority of species have three dorsal setae on tarsus IV.

Lohmannella njoerdri Bartsch, 2020

Lohmannella njoerdri Bartsch, 2020: 278-281, figs. 1-16.

Short description. Length of idiosoma $310 \mu \mathrm{m}$ (male). AD hexagonal, major part of PD rectangular. OC with two corneae. Gland pores vestigial. Length of gnathosoma 0.6 times that of idiosoma. Rostrum longer than gnathosomal base. Length of P-2 5.8 times the diameter. All legs shorter than idiosoma. Tibiae I with six bipectinate ventral setae. Tarsus IV with three dorsal setae. Claws very slender.

Norwegian record. Sula Ridge, $64^{\circ} 05^{\prime} \mathrm{N}, 8^{\circ} 02^{\prime} \mathrm{E}$, $285 \mathrm{~m}$, extracted from small pieces of Lophelia sp.(Scleractinia) (Bartsch 2020).
Further records. None.

Biology. The claws on the tarsi of L. njoerdri are slenderer and longer than in the majority of Lohmannella species. Slender claws often seem to be correlated with life in a soft surface ooze. An example is Halacarus longiunguis Police, 1909, its long claws are expected to find several stepping points and in that way prevent the mite from sinking into deeper sediment layers (Bartsch 2007b). But, in contrast to Halacarus longiunguis, the legs of Lohmannella njoerdri are short, not meant to raise the mite above the ground. The mode of life of $L$. njoerdri is not known.

Remarks. Four Lohmannella species have been mentioned from Norway, namely L. falcata, $L$. njoerdri, L. norvegica and $L$. sulensis. The most striking character of $L$. njoerdri is the shape of the claws; they are unusually long and slender. Other distinguishing characters are: tarsus IV of $L$. falcata and L. sulensis has four dorsal setae, L. njoerdri three setae, the rostrum of $L$. norvegica is shorter than the gnathosomal base, that of L. njoerdri is longer.

\section{Lohmannella norvegica K. Viets, 1927}

Lohmannella norvegica K. Viets, 1927a: 149, 150, figs. 86-92.

Short description. Length of female $425 \mu \mathrm{m}$. AD hexagonal. OC with two corneae. PD anteriorly rectangular. Length of gnathosoma $205 \mu \mathrm{m}$, i.e. slightly less than half the length of idiosoma; rostrum shorter than gnathosomal base. P-2 short, length more than four times the basal part diameter. Legs short. Tibia I with three pairs of bipectinate setae. Claws with minute accessory process.

Norwegian records. Bergen (Nordre Bratholmen, amongst red algae from $25 \mathrm{~m}$ depth, and Sten Sund, from Laminaria growing near the low water edge) (K. Viets 1928a).

Further records. No reliable records published. A record from the United Kingdom (England-Cornwall) (Pugh 1988) turned out to be one of L. kervillei Trouessart, 1894 (Somerfield 1991).

Biology. Inhabitant of subtidal substrata.

Remarks. Lohmannella norvegica is one of the few Lohmannella species with a short gnathosoma and rostrum. In the majority of species, the length of the gnathosoma equals 0.7 to 1.0 times that of the idiosoma and the rostrum is longer than the gnathosomal base. Another species from the North-eastern Atlantic, L. kervillei, has an even more compact gnathosoma, the length of P-2 is less than three times the diameter (in basal part). 
Lohmannella sulensis Bartsch, 2020

Lohmannella sulensis Bartsch, 2020: 281-283, figs. 17-32.

Short description. Length $386 \mu \mathrm{m}$ (female). AD 1.5 times wider than long. PD only slightly wider than long; its anterior part wider than posterior half. Length of gnathosoma 0.9 times that of idiosoma. Rostrum longer than gnathosomal base. Palps slender. Length of P-2 seven times the diameter. P-4 slender. Length of P-2 equalling 2.5 times that of P-4. Leg I almost as long as idiosoma, leg IV somewhat longer. Tibia I with six bipectinate ventral setae. Tarsus IV with four dorsal setae.

Norwegian record. Sula Ridge, $64^{\circ} 05^{\prime} \mathrm{N}, 8^{\circ} 02^{\prime} \mathrm{E}$, $285 \mathrm{~m}$ (Bartsch 2020).

Further records. None.

Biology. Extracted from small pieces of the scleractinian Lophelia sp.

Lohmannella sulensis is expected to be primarily a deep-water form.

Remarks. The most obvious characters of Lohmannella sulensis are: a wide AD, namely 1.5 times wider than long; a short PD, compared to the length of the $\mathrm{AD}$; a gnathosoma almost as long as the idiosoma (0.9:1); long and slender palps, length of P-4 about 0.4 times that of P-2; long and slender legs, tibia I with six bipectinate ventral bristles, and tarsus of leg IV with four dorsal setae. None of the presently known North Atlantic species has the combination: AD very wide, gnathosoma long and slender, P-4 long, legs almost as long as the idiosoma.

Genus Makarovana Koçak and Kemal, 2008

Diagnosis. Posterior half of P-2 with two setae. Third and fourth palpal segment with medial spine. Genu I shorter than both telofemur and tibia. These segments with wide, apically dentate spines. Tarsus I with ventral spine.

\section{Makarovana spinosa (Bartsch, 1978)}

Agauopsis spinosa Bartsch, 1978a: 16-20, figs. 25-46.

Short description. Length $440-485 \mu \mathrm{m}$. Surface of dorsum slightly villous. Rostrum shorter than gnathosomal base. P-4 with three setae in basal whorl, one of these spiniform. Leg I with short spines, ventral spines apically widened and dentate, ventromedial spines less spinose. Ventral spine on genu I short, divaricate and dentate, ventromedial spine not divaricate. Ventromedial flank of tibia I with four spiniform slightly dentate setae, of these one slender and three wide and apically slightly divaricate.

Norwegian record. Tromsö (southwestern beach of Kvalöy and southern and northern part of Grindöy) (Bartsch 1978a).

Further records. None.

Biology. At present, only females, nymphs and larvae are known, no males.

The species was most abundant in the upper tidal area of beaches with coarse sediment rich in shell fragments (Bartsch and Schmidt 1979).

Remarks. Makarovana spinosa is similar to a species described under the name Acanthopalpus hirsutus Makarova, 1978, collected in the Gulf of Anadyr and nowadays called Makarovana hirsuta. The two species may be conspecific. Both were described in 1978, the description of M. spinosa appeared October 10, 1978. The publishing data for Makarovana hirsuta is not mentioned.

\section{Genus Maracarus Bartsch, 2016}

Diagnosis. Dorsal plates either uniformly ornamented, often reticulated or with punctate areolae. Dorsum with four pairs of glands, each generally opening to the exterior via a conspicuous canal. AE with pair of epimeral pores. P-2 with one distodorsal seta; P-3 without spur or seta. Genua shorter than telofemora and tibiae. Tibia I with four ventral and three dorsal setae. Tarsi I to IV with 3 , $0-1,0-1,0-1$ ventral setae. Solenidion on tarsus II in dorsomedial position. Tarsus I with three almost equal-sized claws.

Remarks. The genus Arhodeoporus, introduced by Newell (1947), has recently been reevaluated (Bartsch 2016a). The genus Arhodeoporus includes, at present, no more than two species which are spread in the north-western Atlantic. For a few other species, e.g., the European species once described as Halacarus gracilipes Trouessart, 1889, a new genus, Maracarus, has been erected, with Halacarus gracilipes as the type species.

Maracarus gracilipes (Trouessart, 1889)

Halacarus gracilipes Trouessart, 1889b: 243.

Arhodeoporus gracilipes, Newell 1947: 183;

Bartsch 1977b: 627-629, figs. 1-10; Green and MacQuitty 1987: 70, 71 fig. 25 A-E.

Maracarus gracilipes, Bartsch 2016a: 563.

Short description. Length of female 310 $450 \mu \mathrm{m}$, male 304-360 $\mu \mathrm{m}$. Porose areolae on dorsal and ventral plates delicately punctate. Integument between areolae reticulated. OC drawn 
out into long, caudiform projection which posteriad extends far beyond insertion of leg IV. Ventral plates with porose areolae. Female GA with three pairs of pgs. Male GO surrounded by 25-33 pgs. Gnathosoma longer than wide, rostrum short, hardly reaching beyond middle of P-2. Legs slender, all shorter than idiosoma. Tibia I with four ventral setae, all slender and smooth, tibia II ventrally with two bipectinate and two smooth bristles, tibia III with one bipectinate and one smooth bristle, and tibia IV with two smooth ones. Tarsi I to IV with 3, 1, 0, 0 ventral setae.

Norwegian records. Bergen (Osund/Kvernepollen, Stensund, subtidal) (K. Viets 1928a); Tromsö (northern edge of Grindöy) (Bartsch and Schmidt 1979).

Further records. North-eastern Atlantic from northern Africa (Senegal) and Azores to northern Norway, namely Denmark, Eire, France, Germany, the United Kingdom (England, Northern Ireland, Wales), Spain, Sweden. The Mediterranean: Italy, France, Monaco, Turkey; the Black Sea: Bulgaria, Crimea, Russia (Caucasian coast) (K. Viets 1956; Riesgo et al. 2010; Bartsch 2004a, 2016a; Durucan 2019b).

Biology. Inhabitant of constantly wet lower tidal and subtidal sediments. The identity of a deepwater record from the Bay of Biscay, 1,410 m (Trouessart 1896), is in need of verification.

Remarks. Another species, namely Maracarus minor (Bartsch, 1977), is in dorsal aspect similar to $M$. gracilipes. The former is spread in the northeastern Atlantic (France; the United Kingdom (England, Northern Ireland)) (Bartsch 1977b; Green and MacQuitty 1987) and the Mediterranean (France, Golfe de Lion - coll. C. Poizat, unpublished record). At present, there are no records of M. minor from Norway. Maracarus minor, with its idiosomal length of $267-300 \mu \mathrm{m}$, is smaller than $M$. gracilipes, the ventral plates are slenderer and the porose areolae distinctly smaller or lacking.

\section{Genus Metarhombognathus Newell, 1947}

Diagnosis. Idiosomal plates of adults small, areas of striated integument large. Tarsi without midventral setae. Several gland pores replaced by short setae. Gnathosoma about as long as wide; rostrum much shorter than gnathosomal base, palps four-segmented, but P-3 reduced to minute sclerite. Tibiae I to IV each with pair of spiniform, pectinate ventral setae. Tarsi I and II each with one spiniform ventral seta and eupathid doubled pas, tarsi III and
IV without ventral setae; pas short, flattened. Tarsi end with three claws.

Dorsal and ventral plates of deutonymphs distinctly larger than in adults whereas in the majority of halacarids the plates of juveniles are smaller than in adults.

Metarhombognathus armatus (Lohmann, 1893) Rhombognathus armatus Lohmann, 1893b: 18. Rhombognathopsis armatus, K. Viets 1927a: 108-111, figs. 28-30.

Rhombognathus mollis, K. Viets 1927a: 111113, figs. 31-38.

Metarhombognathus armatus, Newell 1947: 63-68, figs. 36-53; Bartsch 1975b: 195, 196, fig. 7a-d; Green and MacQuitty 1987: 30, 31, fig. 9A-D.

Short description. Length of adults 320-612. Dorsal and ventral plates (AD, pair of OC, PD; pairs of $\mathrm{AE}$ and $\mathrm{PE}, \mathrm{GP}$ ) very small; length of dorsal plates less than 0.3 of idiosomal length. Pairs of anterior epimeral plates in the median separated by striated integument. All tarsi end with three strong claws. Paired claws with delicate tines along their shaft.

Norwegian records. Bergen (Skutevikencoll. H. Ringvold); Tromsö (Grindöy) (Bartsch and Schmidt 1979).

Further records. North-western Atlantic: Canada (New Brunswick), the United States (North Carolina to Rhode Island); North-eastern Atlantic, the North Sea and the Baltic included: France (Bay of Arcachon) to Greenland (eastern coast) (Bartsch 1979c, 1982).

Biology. Most abundant amongst thalli of green algae (Enteromorpha, Blidingia), growing on rocks and wooden pilings, also living on green algal films on barnacles and brown algae (Fucus). Present in the midtidal and lower tidal zone. Often very abundant. Records are from a salinity range from 6 to 33\%o (cf. Bartsch 1974a).

Remarks. Another Metarhombognathus species, namely M. nudus (K. Viets, 1928), is expected to be found on the coast of Norway, especially in the northern part. The dorsal and ventral plates of adult $M$. nudus are very small, as in M. armatus, and the legs bear three large-sized claws (K. Viets 1928b). In M. nudus a few tines are present at the apical part of the lateral claws whereas in $M$. armatus these tines are lacking. Deutonymphs of the two species can be separated on the basis of (1) the shape of the AE: in M. ar- 
matus the epimera are fused to a ventral plate, in M. nudus the epimera are separated in the median by striated integument; and (2) the lateral claws: apically almost smooth in $M$. armatus vs. with a few large tines in M. nudus. Metarhombognathus nudus is expected to colonize more "rough" regions, colder and/or more wave-beaten than those inhabited by M. armatus (Bartsch 1979c).

\section{Genus Rhombognathides K. Viets, 1927}

Diagnosis. Dorsal plates of adults large, may even be fused; areas with striated integument between plates narrow. Ocular plates often with three setae, two of them representing setiform gland pores. In females, genital opening terminal and covered by two solid genital plates. Gnathosoma hardly longer than wide. Rostrum much shorter than gnathosomal base. Palps three-segmented, flattened. Genua shorter than both telofemora and tibiae. Tibiae I and II with pair of ventral setae, tibiae III and IV with two ventral setae (rarely one). Tarsi with pair of lateral claws, these smooth, with small accessory process or angled and with pectines. Median claw ranging from absent to almost as long as lateral claws but never bearing pectines.

Biology. Species of the genus Rhombognathides are mainly algivorous.

Remarks. The species can be separated on the basis of the shape and the number of the claws.

Rhombognathides mucronatus (K. Viets, 1927) Rhombognathopsis mucronatus K. Viets, 1927a: 113-115, figs. 39-42, 43a, b, 44a, b.

Rhombognathides mucronatus, Newell 1947:

54-56, figs. 24-26; Bartsch 1972: 178, fig. 9; Green and MacQuitty 1987: 38, 39, fig. 12A-C.

Short description. Length of females 407$487 \mu \mathrm{m}$, of males 383-450 $\mu \mathrm{m}$. Paired claws on all tarsi angled and with rake-like pectines. Median claw on all tarsi scythe-shaped; length of median claw on tarsi I and II at least $3 / 4$ of that of lateral claws, length of median claws on posterior legs somewhat smaller.

Norwegian records. Bergen (Lindås/Fanebust, Nautevågen — coll. H. Ringvold); Tromsö (Grindöy) (Bartsch and Schmidt 1979).

Further records. Western North Atlantic, from New Brunswick (Canada) to Connecticut (the United States). Eastern North Atlantic from France (the Bay of Arcachon) to Russia (White Sea) (Bartsch 1976c, 1978a; Nikitina 2013). Further records are from Denmark, Eire, the German North
Sea and the Baltic coast, the Netherlands, and the United Kingdom (England, Northern Ireland, Scotland, Wales) (Bartsch 1972; Green and MacQuitty 1987; Somerfield 1988; Bartsch and Smit 2006). In the Baltic, this species is spread eastward to the island Hiddensee (salinity $8 \%$; unpublished record).

Biology. Algivorous. Inhabitant of coarse sand, salt marshes, clumps of Modiolus sp. (Bivalvia), green algae, thalli of Fucus sp. and holdfasts of Laminaria sp. (brown algae) (Bartsch 1972, 1979a). Most common within a salinity range of $7-20 \%$.

Remarks. Rhombognathides mucronatus is one of the species in which the paired claws are rake-like. In contrast to other similar-looking species, the median claw on the tarsi has a length of more than $1 / 2$ of that of the paired claws.

Rhombognathides pascens (Lohmann, 1889) Aletes pascens Lohmann, 1889: 322-324, pl. 6 , figs. $6,15,19,20,45-48$; pl. 7, figs. 53, 64-66, 70, 76-78.

Rhombognathides pascens, Newell 1947: 48-51, figs. 12-19; Bartsch 1972: 174, 175, fig. 6; 1996: 142-144, figs. 1-7; Green and MacQuitty 1987: 40, 41, fig. 13A-C.

Short description. Length of females 290$414 \mu \mathrm{m}$, of males $281-385 \mu \mathrm{m}$. Paired claws on all tarsi angled and with rake-like pectines. Claws on tarsi I and II with small median claw; on tarsi III and IV median claw vestigial.

Norwegian records. Kristiansand (Artsdatabanken 2019); Stavanger (Vikedal camping — coll. H. Ringvold); Bergen (Bogneströmmen/Mangerfjord, Nordre Bratholmen, Turöy, Osund, Herdla, Herdla Sund, Hatte Sund/Roslags Vaag, Rogne Sund (K. Viets 1928a) and Kyrkjetangen/Nordnesvatnet, Nordheimsund-coll. H. Ringvold); Tromsö (Grindöy) (Bartsch and Schmidt 1979).

Further records. Western North Atlantic: Canada (Nova Scotia); the United States (Connecticut to Massachusetts). Eastern North Atlantic and the North Sea, the Baltic, the Black Sea and the White Sea. Records from the North Atlantic range from Spain and the Azores to the White Sea, in the Baltic as far north and east as Finland, Poland and Estonia and in the Black Sea along the northern and southern coastlines (Bulgaria, Crimea, Romania, Turkey, Ukraine) (Bartsch 2004a, 2009; Krivolutsky and Antsiferova 2008).

Biology. Inhabitant of lower tidal and subtidal green, brown and red algae. Rhombognathides pascens is one of the few species regularly found 
on the large thalli of Laminaria sp. (brown algae; personal observation). Common on exposed shorelines. Still present in brackish water of about $4 \mathrm{~S} \%$ o (cf. Bartsch 1974a).

Remarks. At present, it is the only Rhombognathides species with the combination: of paired claws rake-like claws and the median claw lacking on tarsi III and IV.

Rhombognathides seahami (Hodge, 1860)

Rhombognathus seahami Hodge, 1860: 319, pl. 16, fig. 1a-c.

Rhombognathides seahami, Newell 1947: 51-54, figs. 20-23; Bartsch 1972: 175-178, fig. 7; 1975b: 195, fig. 6a-c; Green and MacQuitty 1987: 42, 43, fig. 14A-C.

Short description. Length of females 390 $458 \mu \mathrm{m}$, of males $327-433 \mu \mathrm{m}$. Paired claws on all tarsi angled and with rake-like pectines. Claws I to IV with small median claw, on claws III and IV median claw distinctly smaller than on legs I and II.

Norwegian records. Kristiansand (Artsdatabanken 2019); Stavanger (Lysebotn, Vikedal camping-coll. H. Ringvold); Bergen (Mundheim, Røyrvik, Grönevika, Tellnes pier, Nordnes - coll. H. Ringvold) and Bogneströmmen, Turöy, Osund/ Kvernepollen, Herdla, Kalsöy, Hjeltefjord, Rylands Sund, Hatte Sund/Rosland Vaag, Stensund) (K. Viets 1928a); Trondheim (Korsvika — coll. H. Ringvold); Tromsö (Grindöy) (Bartsch and Schmidt 1979).

Further records. Western North Atlantic: Canada (Nova Scotia); the United States (Connecticut to Rhode Island). Eastern North Atlantic and the North and White Sea: from Spain to Russia; the Baltic: north to Estonia and Finland (Krivolutsky and Antsiferova 2008; Bartsch 2009; Carlton et al. 2020).

Biology. Inhabitant of lower tidal and subtidal green, brown and red algae, their thalli and hapteres. Rarely extracted from sandy deposits. Found within a salinity range from about (1-)3-32\%.

A female and a few nymphs, collected in September and October 2016 near Stavanger (Lysebotn) and Bergen (Røyrvik), were inhabited by the peritrich ciliate Cothurnia sp. (Peritrichea). The ciliates, $1-11$ per mite, were fixed to the basal leg segments, mainly to the two pairs of front legs. The smooth, hyaline, somewhat compressed loricae of Cothurnia sp. had a length of 35-40 $\mu \mathrm{m}$, a width of 18-22 $\mu \mathrm{m}$ in the middle part and a smaller opening of about $11 \mu \mathrm{m}$. The short $(15-20 \mu \mathrm{m})$ stalk was fixed to the mite with a basal disc. In some individuals, the zooid was completely withdrawn into the lorica, in others it was extended, reaching beyond the lorica. The zooid was fixed to the bottom of the lorica with a $5 \mu \mathrm{m}$ long style.

Remarks. The shape of the dorsal plates and the rake-like paired claws of Rhombognathides seahami are similar to those of $R$. mucronatus and $R$. pascens; however, the tarsi III and IV have a median claw (absent in $R$. pascens) and this median claw is distinctly shorter than that of legs I and II (in R. mucronatus, its length is more than half that of paired claws).

Rhombognathides spinipes (K. Viets, 1933)

Rhombognathus spinipes K. Viets, 1933a:

267-269, figs. 8a, b, 9a, b, 10a, b.

Rhombognathus spinipes, Willmann 1952: 166, 167, p1. 28, 21a-c.

Rhombognathides spinipes, Bartsch 1972: 178-

180, figs. 11A-G, 12A-F; Green and MacQuitty 1987: 44, 45, fig. 15A-D.

Rhombognathus aculeatus Sokolov, 1952: 5860, fig. 19, 1 and 2.

Short description. Length of females 280 $430 \mu \mathrm{m}$, of males $365-439 \mu \mathrm{m}$. Dorsal plates AD, $\mathrm{OC}$ and PD fused to a shield. Basidorsal setae of tarsi I to IV short, spiniform; apical fossary setae slender. Paired claws of tarsi smooth, median claw lacking.

Norwegian record. Bergen (Sandholna-Calm bay, Sandholna-by swing-coll. H. Ringvold); Svalbard (puddle near Grønfjordbreen; $77^{\circ} 58^{\prime} \mathrm{N}$, $14^{\circ} 16^{\prime} \mathrm{E}$ ) (Chertropud et al. 2017).

Further records. Northwestern Atlantic and the Arctic Ocean (Barents Sea and White Sea): Eire, France (Bay of Arcachon, Roscoff), Russia, the United Kingdom (England, Wales); the North Sea and the Baltic: Germany, the Netherlands (Sokolov 1952; Bartsch 1975a, 1976c; Green and MacQuitty 1987; Somerfield 1991; Bartsch and Smit 2006; Krivolutsky and Antsiferova 2008).

Biology. Often found in high numbers in salt marshes, amongst the surface layer of sediment and algae; also extracted from brown algae (Fucus spiralis). Found within a salinity range from $8-32 \%$. In experiments, the mites proved to be able to survive in freshwater for several weeks (Bartsch 1974a), consequently, long-term rainfall or being covered by melting snow should not seriously affect the mites.

Remarks. At present, this is the only Rhombognathides species in which the dorsal seta on the tarsi is spiniform, the paired claws are smooth, and a median claw is lacking. 
Rhombognathides trionyx (Trouessart, 1899) Rhombognathus trionyx Trouessart, 1899: 210. Rhombognathus trionyx, André 1939: 310312, fig. 2 .

Rhombognathides merrimani merrimani and R. merrimani needleri Newell, 1947: 56-60, figs. 27-35.

Rhombognathides merrimani, Bartsch 1975a: 74-76, fig. 135, 136; Green and MacQuitty 1987: 36, 37, fig. 11A-C.

Rhombognathides trionyx, Bartsch 1975a: 75, figs. 133, 134.

Short description. With two subspecies. Length of Rhombognathides trionyx merrimani females 316-353 $\mu \mathrm{m}$, of males 310-341 $\mu \mathrm{m}$, of $R$. trionyx needleri females 322-359 $\mu \mathrm{m}$, of males 292-335 $\mu \mathrm{m}$. Tarsi I and II with two (subspecies merrimani) or three claws (subspecies needleri), tarsi III and IV with two claws. All claws smooth.

Norwegian records. Kristiansand (Artsdatabanken 2019); Tromsö (Grindöy) (Bartsch and Schmidt 1979).

Further records. Western North Atlantic: Canada (New Brunswick). Eastern North Atlantic: Eire, France (Bay of Arcachon, English Channel), the Netherlands, the United Kingdom (England, Northern Ireland, Wales) (Newell 1947; Bartsch 1975a, 1976c; Green and MacQuitty 1987; Somerfield 1991; Bartsch and Smit 2006).

Biology. Abundant on tidal beaches amongst pebbles and sand with algae; also present in algal scrubs and, though in low numbers, on Fucus sp. (brown algae) and Ulva sp. (green algae) (Bartsch 1979a). Inhabitant of the tidal zone from the upper to the lower tide mark and of mesohaline brackish to marine coastlines.

Remarks. Rhombognathides trionyx is characterized by its smooth paired claws and slender dorsal setae on the tarsi.

Newell (1947) described two subspecies, Rhombognathides merrimani merrimani, with two claws on all tarsi, and Rhombognathides merrimani needleri, with three claws on tarsi I and II; accordingly $R$. m. needleri is a junior synonym of $R$. trionyx and $R$. m. merrimani is called $R$. trionyx merrimani.

\section{Genus Rhombognathus Trouessart, 1888}

Diagnosis. Dorsal and ventral plates present, two or more may be fused. Each OC with two setae, PD with one or two pairs of setae. Most species with ventral shield (AE, PE, GP fused). AE and PE often with marginal (adjunct) setae in addition to the three pairs of setae on AE and four pairs on PE. Gnathosoma slightly longer than wide. Rostrum about as long as gnathosomal base. Palps foursegmented. Legs slender. Genua shorter than the legs' telofemora and tibiae. Tibiae I to IV of most species with a pair of ventral setae. Ventral setae on tibia I bipectinate. Tarsi I to IV with paired claws, median claw lacking. With rod-like carpite between tip of tarsus and claws.

Biology. Mainly algivorous. Inhabitants of tidal and subtidal substrata, in the tidal area from the upper to the lower fringe.

Rhombognathus magnirostris lionyx Trouessart, 1899

The identity of the specimens is not known. They were collected in the Sorgfjord (Baie Treurenberg), $79^{\circ} 58^{\prime} \mathrm{E}, 16^{\circ} 52^{\prime} \mathrm{E}$, Svalbard, extracted from dredged algae from $22 \mathrm{~m}$ depth (Trouessart, 1899).

Rhombognathus notops (Gosse, 1855)

Pachygnathus notops Gosse, 1855b: 305-306, pl. 8, figs. 1-4.

Rhombognathus notops, Newell 1956: 468471, figs. 1-11; Bartsch 1975a: 54; Green and MacQuitty 1987: 48, 49, fig. 26A-F.

Short description. Length of females 333$415 \mu \mathrm{m}$, of males 315-390 $\mu \mathrm{m}$. Dorsal plates separated by distinct areas of striated integument. OC smaller and shorter than AD. PD with single pair of setae in anterior third of plate. AE, PE, GP, and AP fused. Both $\mathrm{AE}$ and $\mathrm{PE}$ with a pair of adjunct setae. Tibiae I to IV with 2, 1, 1, 2 bipectinate ventral setae. Accessory process on apex of claws with 9-13 tines.

Norwegian records. Bergen (mentioned as R. magnirostris) (Turöy, Herdla/Hjeltefjord, Hatte Sund, Sten Sund) (K. Viets 1928a).

Further records. Eastern North Atlantic, including the North Sea and the Baltic: Denmark, Eire, France, Germany (Heligoland), Spain, the United Kingdom (England, Northern Ireland, Scotland, Wales) (Bartsch 1975a; Green and MacQuitty 1987; Somerfield 1991). Records from the Mediterranean and the Black Sea (K. Viets 1940) are in need of verification.

Biology. The species is algivorous; it inhabits lower tidal and subtidal algae and their epibios.

Remarks. The original description in Gosse (1855b) offered limitid data (length $1 / 87^{\text {th }}$ of an inch, body rather slender, gnathosoma short, claws with narrow accessory process), which consequently resulted in unreliable identifications. No 
type locality was given but the types obviously had been collected on the shores of southwestern England. On the basis of material collected on the south coast of England, Newell (1956) redescribed this species. A slide in K. Viets' Norwegian halacarid collection, labelled Rhombognathus magnirostris, agrees with the characters of $R$. notops.

Rhombognathus subtilis Bartsch, 1975

Rhombognathus subtilis Bartsch, 1975a: 6164, figs. 42-59.

Rhombognathus subtilis, Green and MacQuitty 1987: 50, 51, fig. 17A-D.

Rhombognathus magnirostris lionyx, K. Viets 1927b: 11, figs. 20 and 21.

Short description. Length of females 328$390 \mu \mathrm{m}$, of males 298-341 $\mu \mathrm{m}$. OC large, longer than AD. PD extending anteriad to about the level of insertion of leg III. AE, PE and GP fused to a ventral shield. In both female and male a distinct area of striated integument present between this shield and anal plate. AE with two to three pairs and PE with single pair of adjunct setae. Tibiae I to IV with 2, 1, 1, 1 bipectinate ventral setae. All legs with long sclerite between tip of tarsus and claws. Claws smooth.

Norwegian records. Bergen (mentioned as R. magnirostris lionyx) (Herdla, low water edge) (K. Viets 1928a); Tromsö (Grindöy); Svalbard (Ny Ålesund) (Bartsch 1978a; Bartsch and Schmidt 1979).

Further records. Northwestern Atlantic: Eire, England, France (Bay of Arcachon, Gironde and Roscoff, Bretagne) (Bartsch 1975a; Green and MacQuitty 1987; Somerfield 1988).

Biology. Inhabitant of tidal algae and sediment.

Remarks. Rhombognathus subtilis has often been recorded as $R$. lionyx Trouessart, 1899. Newell and André (1959) restudied Rhombognathus species described by E.L. Trouessart, also a slide labelled Rhombognathus magnirostris, variété $l i$ onyx n.var. with a single female collected near Saint-Vaast-la-Hougue (English Channel). The idiosoma of the individual is damaged but the legs show an important detail, namely the tarsal claws have a delicate accessory process. A similar process was found on the claws of a female dredged in the Bai de Morlaix (English Channel), at a depth of 13 m (Bartsch 1980). Rhombognathus lionyx may be an inhabitant of subtidal substrata, whereas R. subtilis is most abundant in the tidal area.

K. Viets (1936: fig. 630) shows a ventral aspect of a female which seems to be a $R$. subtilis, not a $R$. notops.

\section{Genus Simognathus Trouessart, 1889}

Diagnosis. Dorsal and ventral plates strongly sclerotized. AD and PD large, surface often foveate. OC distinctly smaller or largely reduced. Conical rostrum shorter than almost spherical gnathosomal base. Palps three-segmented and dorsally attached to gnathosoma. Genu I much shorter than telofemur and tibia. Tarsus I shorter and slenderer than following tarsi and with a single tapering ventral seta. Tarsus I ending with large, smooth median claw and almost setiform paired claws. Tarsi II to IV with large paired claws, median claw reduced to minute central sclerite.

Simognathus minutus (Hodge, 1863)

Pachygnathus minutus Hodge, 1863: 301-302, pl. 16, figs. 10, 11.

Pachygnathus sculptus Brady, 1875: 306, 307, pl. 42, figs. 1-6.

Simognathus sculptus, André 1946: 136-138, figs. 78, 79.

Simognathus minutus, Bartsch 1974b: 276-

179: figs. 1-20; Green and MacQuitty 1987: 136, 137, fig. 56A-D.

Short description. Length of female 526$530 \mu \mathrm{m}$. Dorsal plates foveate. AD and PD elongate, length of $\mathrm{OC}$ about $1 / 3$ of that of $\mathrm{AD}$. PD including and anteriad extending beyond pair of ds-4. Marginal parts of AE foveate, median part uniformly porose. Second palpal segment with ventral protruding and seta. Tibia I ventrally with one massive, rather short and tapering spine and one rather slender bristle-like seta. Tibiae II to IV with pair of bipectinate bristles.

Norwegian records. Kristiansand (Artsdatabanken 2019); Bergen (Bognströmmen, red algae from $25 \mathrm{~m}$ depth, and Osund, subtidal brown algae, Laminaria) (K. Viets 1928a).

Further records. North-eastern Atlantic: from Norway to Spain (K. Viets 1956; Green and MacQuitty 1987; Riesgo et al. 2010).

Biology. Inhabitant of lower tidal and shallow subtidal algae and sandy deposits.

Remarks. From the English Channel area a second Simognathus species is known, i.e. Simognathus leiomerus Trouessart, 1894. The species is smaller (length 365-403 $\mu \mathrm{m}$ ), the OC are reduced to small, elongate sclerites, and on the P-2 the ventral protruding and the seta are fused (Trouessart 1894c).

\section{Genus Thalassarachna Packard, 1871}

Diagnosis. Dorsal plates often reticulate but without raised sculpturing. Male PD in some spe- 
cies somewhat larger than female PD. Idiosoma generally with four pairs of gland pores. Gnathosoma longer than wide. Palps four-segmented. P-2 with one distodorsal seta. P-3 with medial spine. Genu I shorter than both tibia and telofemur I. Tibia I with bristle-like or spiniform ventral setae, telofemur I often with similar setae. Tarsi I and II with more than three dorsal setae.

Thalassarachna basteri (Johnston, 1836)

Acarus basteri Johnston, 1836: 353-355, fig. 51a and b.

Halacarus (Thalassarachna) basteri, Newell 1947: 102-106, figs. 143-154.

Thalassarachna basteri, Green and MacQuitty 1987: 120, 121, fig. 4A-D; Bartsch 2015b: 230-233, figs. 1A-F, 2A-J.

Short description. Length $864-1,197 \mu \mathrm{m}$. AD longer than wide and with bluntly ending frontal spine. OC short, narrow. Female GA with three to four pairs of pgs. In males GA with about $110 \mathrm{pgs}$, these densely arranged around GO. Gnathosoma longer than wide. Rostrum extending to or just beyond P-2. Telofemur I with three ventral spines, tibia I generally with 8 ventral setae, 6 of these spiniform. Tarsi I and II each with (8-)9 dorsal setae (solenidion included).

Norwegian records. Kristiansand (Artsdatabanken 2019); Bergen (Bogneströmmen, Nordre Bratholmen, Turöy, Osund/Kvernepollen, Herdla/ Sjaten ved Kalsöy, Hjeltefjord, Herdla Sund, Rylands Sund, Rosland Vaag) (K. Viets 1928a); Tromsö (Grindöy); Finmark (Gamvik) (Bartsch 1978a, 2015b).

Further records. Western North Atlantic: the United States and Canada (Connecticut to Quebec). Eastern North Atlantic and adjacent seas (Russia (Nowaja Zemlya) to Spain), the Mediterranean, the Baltic (Bartsch 2015b).

Biology. Inhabiting various substrata from the low water edge to a depth of $25 \mathrm{~m}$, namely colonial organisms such as hydroids, bryozoans, bivalves, tubes of serpulid polychaetes, various algae (green, brown, red), hapteres of Laminaria (brown algae), and sediments rich in organic material. Found within a salinity range of 2-32\%o.

Remarks. A similar though slightly shorter frontal spine is present in Thalassarachna princeps (Trouessart, 1902). The latter species has five ventral spines on telofemur I whereas T. basteri has three such spines.
Thalassarachna caecoides (Bartsch, 1978)

Halacarellus caecoides Bartsch, 1978b: 48-52, figs. 1-10.

Short description. Length $730 \mu \mathrm{m}$ (female). Wide areas of striated integument between anterior and posterior dorsal plates. Ocular plates minute. Narrow PD reaching halfway between levels of ds-4 and ds-5. Each PE with one dorsal and two ventral setae; one pair of setae in striated integument between PE. Legs slender. Rostrum reaching to end of P-2. Ventral setae on telofemora rather slender, not markedly spiniform. Tibia I with 7-8 short ventral setae. Tarsi I and II with five dorsal setae each (solenidion included). Claws on tarsi smooth.

Norwegian record. Norwegian Basin, $64^{\circ} 24^{\prime} \mathrm{N}$ $1^{\circ} 44^{\prime} \mathrm{E}$ (Bartsch 1978b).

Further records. None.

Biology. The single record is from the deep-sea, from 2,615 $\mathrm{m}$ depth. The halacarid mite was extracted from a sample which included sponges and hydrozoans (Bartsch 1978b).

Remarks. Unusual though not unique is the reduction of the ocular plates. Similar reduced plates are present in T. alvina Bartsch, 1994, a deep-sea species just as T. caecoides (Bartsch 1994). A difference between the species is that the PD of T. alvina extends anteriad only slightly beyond the level of ds-5; in T. caecoides the PD of is distinctly longer.

Thalassarachna coeca (Trouessart, 1902)

Halacarus coecus Trouessart, 1902: 68.

Halacarellus coecus, Bartsch 1983b: 49-51, figs. 1-11.

Short description. Length of male $731 \mu \mathrm{m}$, width $425 \mu \mathrm{m}$. Ocular plates slender, posteriorly tapering, about as long as AD. Anterior margin of PD narrowly ovate, plate about twice as long as AD. Male with GO in middle of genital plate. GO surrounded by 44 pgs. Rostrum reaching somewhat beyond the level of middle P-2. Tibia I with four pairs of ventral bristles, basal ones spiniform, apical ones slenderer and longer. Tibia I to IV ventrally with $8,8,6$ slender setae. Tarsus I with 8 dorsal setae (short dorsolateral solenidion included).

Norwegian record. Northern Atlantic: off south-eastern coast of Svalbard, near Hopen Island, $76^{\circ} 30^{\prime} \mathrm{N}, 25^{\circ} 27^{\prime} \mathrm{E}, 48 \mathrm{~m}$ (Trouessart 1902).

Further records. None.

Biology. The species was extracted from gravelly sediment, from a depth of $48 \mathrm{~m}$. 
Remarks. Thalassarachna coeca is a rather large-sized species. It differs from the similar-sized Thalassarachna hexacantha (outlined below) by more elongate $\mathrm{OC}$, narrower PD, much smaller number of pgs, shorter rostrum, and larger number of ventral setae on tibiae I to IV.

Thalassarachna hexacantha (K. Viets, 1927)

Halacarellus hexacanthus K. Viets, 1927a: 124-126, figs. 50-55; 1927b: 20, 21, figs. 43, 49.

Short description. Length $865-930 \mu \mathrm{m}$. Anterior margin of AD truncate. Pair of ds-4 in both female and male in striated integument. Female PD slightly longer than wide, its arched to ovate anterior margin anteriad not extending to the level of ds-4. PD in male larger than in female; its arched (or slightly truncate) anterior margin reaching just beyond the level of ds-4. GA of females only slightly extending beyond anterior margin of GO; plate with up to five pairs of pgs (K. Viets 1927a). Male GA distinctly extending beyond GO; distance from anterior margin of GA to GO and from GO to basis of anal sclerites about the same as length of GO. Male GA with almost 200 pgs. Rostrum slender, reaching the end of P-3. Legs slender, legs I to III shorter than idiosoma, leg IV as long or slightly longer than idiosoma. Tibiae I to IV with $6,4,4,4$ smooth ventral setae. Tarsi I to IV with 6-8, 6, 4, 4 dorsal setae (solenidia included). Claws with pectines.

Norwegian records. Bergen (Herdla Sund, shell fragments from $10 \mathrm{~m}$ depth) (K. Viets 1927a); Tromsö (Grindöy) (Bartsch 1978a).

Further records. North-eastern Atlantic and Arctic Ocean: Denmark, Russia (the White Sea), Sweden, the United Kingdom (Northern Ireland) (K. Viets 1956; Bartsch 1991a; Somerfield 1991; Krivolutsky and Antsiferova 2008).

Biology. Found amongst shallow water algae. This seems to be one of the Thalassarachna species in which adults directly leave the protonymphal skin, a second nymphal stage is suppressed (Bartsch 2015c).

Remarks. Characters distinguishing Thalassarachna hexacantha from $T$. coeca have been mentioned above, those separating $T$. hexacantha from $T$. robusta are mentioned below.

Thalassarachna longipes (Trouessart, 1888)

Leptopsalis longipes Trouessart, 1888: 755.

Halacarellus longipes, K. Viets 1927a: figs. 48, 49; 1927b: 20, figs. 93, 95-97.
Halacarus (Thalassarachna) longipes, Newell 1947: 126-129, figs. 192-196.

Short description. Length 410-624 $\mu \mathrm{m}$. Anterior margin of AD truncate. Female PD short, hardly as long as wide, male PD ovate, 1.3 times longer than wide. Anal valves prolonged, extending beyond anal sclerites. Male GA with 90-100 perigenital setae arranged around GO. Distance from anterior margin of GO to that of GA equalling length of GO. Gnathosoma slender, twice as long as wide. Tip of rostrum extending beyond P-2. Legs slender, leg I somewhat shorter, legs III and IV longer than idiosoma. Tibia I with 7-8 smooth ventral setae. Claws with numerous small tines.

Norwegian record. Bergen (Hattesund, Stensund), extracted from stems of Laminaria (K. Viets 1928a).

Further records. Northwestern Atlantic: Canada (Nova Scotia), the United States (Connecticut to Maine); Northeastern Atlantic, North Sea and the Baltic: Eire, France, the United Kingdom (England), Germany, Denmark, Sweden (Anderson 1933; K. Viets 1956; Bartsch 1979c, 1982; Somerfield 1991).

Biology. Records of $T$. longipes are from lower tidal and subtidal areas; from brown and red algae (Chondrus sp., Ascophyllum sp., corallines) and the decapod Libinia sp.

Remarks. Amongst the presently known Thalassarachna species, $T$. longipes is the only one with prolonged anal valves.

Thalassarachna princeps (Trouessart, 1902)

Halacarus spinifer princeps Trouessart, 1902: 69.

Halacarellus princeps, Bartsch 1983b: 51, 53-57, figs. 12-21.

Short description. Length of male $1,002 \mu \mathrm{m}$, width $661 \mu \mathrm{m}$. AD with wide frontal spine. Anterior and posterior margin of OC arched. PD elongate, almost rectangular, anterior margin arched. Surface of plate reticulated. Anterior part of male GA oviform; GO surrounded by at least 135 pgs. Rostrum reaching to about the end of P-2. Leg I with solid ventral spines, telofemur I with five such spines, genu I with one short and one slenderer, tapering spine, and tibia I ventrally with six spines and apically with pair of bristle-like setae. Tibia II with six (three pairs) of ventral setae, tibiae III and IV each with four ventral setae.

Norwegian record. Off south-eastern coast of Svalbard (near Hopen Island, $76^{\circ} 30^{\prime} \mathrm{N}, 25^{\circ} 27^{\prime} \mathrm{E}$, $48 \mathrm{~m})$ (Trouessart 1902). 
Further records. None.

Biology. A single specimen was extracted from gravelly sediment in $48 \mathrm{~m}$ depth.

Remarks. With its frontal spine, Thalassarachna princeps is similar to the northern Pacific species T. aculeata (Makarova, 1978) and the northern Atlantic T. basteri. Distinguishing characters are: (1) frontal spine in T. aculeata is longer than in T. basteri and T. princeps; and (2) telofemur I bears five ventral spines in $T$. aculeata and $T$. princeps vs. three in T. basteri. The length of the frontal spine may turn out to vary once more individuals from the Arctic Sea become available for examination. Thalassarachna aculeata may prove to be a junior synonym of $T$. princeps.

Thalassarachna robusta (Bartsch, 1978)

Halacarellus robustus Bartsch, 1978a: 8-10, figs. 1-9.

Short description. Length $434 \mu \mathrm{m}$ (female). OC narrow, shorter than AD. PD anteriorly narrowly ovate. One pair of ventral setae within striated integument. Ovipositor extending anteriad distinctly beyond anterior margin of GA. Rostrum slender, reaching to end of P-3. One pair of maxillary setae in posterior third of gnathosomal base, following pair on basis of rostrum. Tibia I with three pairs of ventral setae, all slender, none spiniform. Tibia II to IV with four (two pairs), four (one pair, two setae in line), and three slender ventral setae. Tarsus I with seven dorsal setae. Lateral claws with pectines.

Norwegian record. Tromsö (southern end of Grindöy) (Bartsch 1978a).

Further records. None.

Biology. Found in the upper slope of a sandy beach.

Remarks. Thalassarachna robusta and T. hexacantha are rather similar but $T$. robusta is much smaller and has a longer PD than T. hexacantha. Also, the PD of $T$. robusta is anteriorly converging whereas the PD of $T$. hexacantha is widely arched.

Thalassarachna striata (Lohmann, 1889)

Halacarus striatus Lohmann, 1889: 342, 343, pl. 6, fig. 26, pl. 8, figs. 113, 117, 118.

Halacarellus striatus, Bartsch 1976b: 103-107, figs. 24-43.

Thalassarachna striata, Green and MacQuitty 1987: 130, 111, fig. 4A-E.

Halacarellus similis K. Viets, 1927a: 131-134, figs. 69-73.
Short description. Length $456-565 \mu \mathrm{m}$. Anterior margin of AD slightly arched, posterior margin truncate. Females with pair of ds- 4 within striated integument, outside PD; female PD reaching the level of ds-4. Male PD longer, ds- 4 situated on PD; PD distinctly passing beyond ds-4. Ovipositor of female extending beyond GA. Male GA large, anteriorly truncate to concave; GO surrounded by ca 70 pgs. Rostrum short, hardly reaching the level of dorsal seta on P-2; rostrum distinctly shorter than gnathosomal base. Number of maxillary setae increased, two to four setae on the rostrum and three to five on the gnathosomal base. Tibiae I with 6 ventral setae, namely three spur-like and three bristle-like. Tarsi I to IV with 6, 6, 3, 3 dorsal setae (solenidia included).

Norwegian records. Kristiansand (Artsdatabanken 2019); Bergen (mentioned as Halacarellus similis) (Osund) subtidal, extracted from Laminaria with epibios (bryozoans-Membranipora) (K. Viets 1927a, 1928a).

Further records. Eastern North Atlantic, the North Sea and the Baltic: Denmark, France (English Channel), Germany, Sweden, the United Kingdom (England, Northern Ireland) (K. Viets 1956; Bartsch 1976b; Green and MacQuitty 1987).

Biology. Amongst lower tidal and subtidal algae and their hapteres.

Remarks. Thalassarachna striata can be separated from congeners because of the increased number of maxillary setae, short rostrum, and spurlike setae on tibia I. The other Thalassarachna species have two pairs of maxillary setae, the ventral setae on tibia I are bristle-like or spiniform but not short and spur-like and in most of the Thalassarachna species the rostrum is extending to or beyond the end P-2.

\section{Checklist of freshwater halacarids}

\section{Genus Porohalacarus Thor, 1922}

Diagnosis. Female GP with 4-15 pairs of slender pgs; its genital sclerites with three to nine external acetabula. Male GP with 10-40 pairs of pgs; genital acetabula posterior to GO. Palps four-segmented; P-2 with two dorsal setae. Third palpal segment with short medial spine. Legs slender. Genu I much shorter than telofemur I.

Porohalacarus alpinus (Thor, 1910)

Halacarus alpinus Thor, 1910. 348-351, figs. 1 and 2.

Porohalacarus alpinus, K. Viets 1927c: 465469, figs. 3-10; Bartsch 1973b: 116-119, 
figs. 1-21; 1987: 85, 86, figs. 2, 3; 2006b: 130-132, figs. 5-9a-f, 5-10a, b; 2011: 497-498, fig. 6A-D; 2018: 88-90, fig. 6A-G; Green and MacQuitty 1987: 164, 165, fig. A-D; Durucan and Boyaci 2019: figs. 8-15.

Short description. Length of females 280 $371 \mu \mathrm{m}$, that of a male $286 \mu \mathrm{m}$. AD and OC with conspicuous spots of black eye pigment. Dorsal plates with reticulate ornamentation. Anterior margin of AD truncate. OC with cornea. Female genital plate with four to five (rarely up to nine) pairs of pgs, each genital sclerite with four to nine external acetabula. In males, GP and AP fused to GA. GO of male surrounded by about 40 perigenital setae. Genital acetabula on a pair of domes posterior to GO. Rostrum shorter than gnathosomal base and hardly extending to middle of P-2. Legs shorter (0.7 times or less) than idiosoma. Tibiae I to IV with 4, 3, 2, 2 ventral setae. Tarsus I with single slender ventral seta, tarsi II to IV without ventral setae. Paired claws with delicate tines.

Norwegian record. Freshwater, Valsand in Gudbrandsdalen, $850 \mathrm{~m}$ a.s.1. (Thor 1910).

Further records. North America: Canada (Ontario, Quebec), the United States (New Hampshire, Rhode Island); South America: Brazil (Rio Grande do Sul); Northern Africa: Algeria; Tropical Africa: Madagascar; Australia (Western Australia); New Zealand (North Island); Europe: Austria, Belgium, Denmark, Finland, France, Germany, Hungary, Iceland, Italy, the Netherlands, Poland, Russia, Sweden, Switzerland, Ukraine, the United Kingdom (England, Scotland, Wales); Northern Asia: Russia (Sakha Republic, Kamchatka, Turkey) (Bartsch 2018; Durucan and Boyaci 2019; Pepato and da Silva Conceição 2020).

Biology. Porohalacarus alpinus is a freshwater species though has also been found in low saline brackish water (ca $6 \mathrm{~S} \%$ ). It is one of the species commonly present in surface waters, namely in ditches, ponds, lakes, more rarely on the banks of rivers. It inhabits water mosses (Fontinalis sp.), vascular plants, the epibios on stalks of Phragmites, interstitia within bulks of bivalves such as Dreissena sp., crabs, and colonies of sponges.

Males are present but extremely rare (Bartsch 1987, 2018).

The feeding of P. alpinus is not known. The majority is expected to be carnivorous, but, as demonstrated by individuals with a green gut content, these mites are also phytophagous.
Remarks. Two variants are known, namely, P. a. alpinus and P. a. brachypeltatus Viets 1927. The above mentioned data refer to $P$. a. alpinus.

Durucan and Boyaci (2019: Table 2) presented data of the length range of individuals from western Turkey, namely 250-312 $\mu \mathrm{m}$. These specimens are somewhat smaller than those from northern Europe. The documented length for females of the latter area is $280-371 \mu \mathrm{m}$.

\section{Genus Porolohmannella K. Viets, 1933}

Diagnosis. Idiosoma flattened. Female genital plate with three pairs of pgs. Gnathosoma with long and slender rostrum. Palps four-segmented, attached dorsally. Third palpal segment with spiniform process but no spine or seta. Legs slender. Genua shorter than adjacent segments. Tarsi with pair of claws.

Porolohmannella violacea (Kramer, 1879)

Leptognathus violaceus Kramer, 1879: 147, pl. 8, figs. 1-4.

Porolohmannella violacea, K. Viets 1933b: 283; Green and MacQuitty 1987: 144-145, fig. 59AC; Bartsch 2006b: 151-152, fig. 5-26a-e; 2007a: 49-56, figs. 1-39.

Short description. Length of females 475 $600 \mu \mathrm{m}$; males not known. Integument of idiosoma, gnathosoma and legs pink to violet. Dorsal plates reticulate. Female with three pairs of slender perigenital setae on large GA. GO almost in middle of GA. Each genital sclerite with two external acetabula and one rather inconspicuous acetabulum inside genital cavity. Gnathosoma slightly less than half length of idiosoma. Legs slender, shorter than length of idiosoma. Tibia I with two pairs of ventral setae; ventromedial setae distinctly pectinate, ventrolateral setae weakly pectinate. Tibiae II to IV with 4, 4, 3-4 ventral setae.

Norwegian record. Kristiansand (Artsdatabanken 2019).

Further records. Very common and widespread in the northern hemisphere. Records are from North America, Europe, and Asia. North American records are from Canada (Alberta, British Columbia, Manitoba, Newfoundland, Northwest Territories, Ontario, Quebec) and the United States (New Hampshire, New York, Rhode Island); European records are from Austria, Belgium, Denmark, Finland, France, Germany, Hungary, Italy, Latvia, Monte Negro, the Netherlands, Poland, Portugal, Romania, Russia (European part), Spain, the United Kingdom; 
also collected on Greenland; Asian records are from Japan and Russia (Siberia) (K. Viets 1956; K.O. Viets 1987; Green and MacQuitty, 1987; Zawal 1998; Pešić 2004; Bartsch 2006b, 2007a; Tolstikov et al. 2005; Smit et al. 2010; Semenchenko et al. 2010; Stolbov et al. 2018).

Biology. Porolohmannella violacea lives in freshwater. It is wide-spread in lentic surface waters, in lakes, ponds and ditches (Bartsch 2007a). At present, only females and juveniles have been mentioned, but no males.

Remarks. No other similar-looking species has, as of yet, been found in Norwegian fresh water.

\section{DISCUSSION}

Norway has a coastline that extends from $58^{\circ} \mathrm{N}$ (southern coast of Norway) to $81^{\circ} \mathrm{N}$ (northern edge of Svalbard), its Exclusive Economic Zone has a range from $56^{\circ}$ to $84^{\circ} \mathrm{N}$ and $3^{\circ} \mathrm{W}$ to $43^{\circ} \mathrm{E}$ (Flanders Marine Institute 2018). Jan Mayen is excluded since no records of halacarids mites from there exist. Samples taken in the Norwegian Exclusive Economic Zone cover depths ranging from the tidal and shallow water to deep-sea areas $(2,615 \mathrm{~m})$ and habitats from rocky, sandy and muddy deposits, coral reefs, belts of small algae, as well as kelp forests. Although one can expect a very diverse halacarid fauna and a long list of Norwegian species, the actual knowledge is poor. The list of halacarids presented in the paper (Table 1) includes three new records, in all, 45 marine and two freshwater species. Further research activities will easily double, more likely triple, the number of species.

The records of the 45 marine species are shown in Fig. 1. The marked difference in the diversity within the study areas is mainly due to the sampling activities and not a result of environmental parameters. Bergen is certainly not a 'hot spot' in respect to the Norwegian halacarid fauna.

Table 2 lists halacarid genera and the number of species found on and around Norway, the United Kingdom and Eire, and the French coast of the English Channel (northern coast of Brittany, Normandy, Hauts de France). According to the list, 60 species have been found in tidal and shallow marine habitats around Great Britain and Ireland is (doubtful records are excluded) and eight species in freshwater habitats (plus one represented by juveniles) (Bartsch 1985a, b; Green and MacQuitty 1987; Somerfield 1991; present paper). From the shores and shallows of northern France (English Channel area) 86 records of marine species exist (Trouessart 1894a, c; André 1946; Monniot 1964, 1967; Bartsch 1979a, 1980, 1984, 1991b). However, the above data are far from presenting a complete number of species. The list of halacarids known from the United Kingdom, Eire and northern France is based on material collected three or more decades ago. At that time, the boundary between warm and cold temperate water masses was expected to be near the western entrance into of the English Channel (Briggs 1974) or in the western part of the North Sea (Hedgepeth 1957). Hence the areas under consideration, namely the northern coast of France, the United Kingdom and Eire, and Norway largely belonged to the boreal zone. New sampling activities should alter the present number of species. This may be due to new records from sites and habitats not studied before and also to an increasing rate of immigrated or introduced species due to changes in climate and habitat as well a greater rate of transport (Gollasch and Nehring 2006; Loebl et al. 2006; Witte et al. 2010; van Beusekom et al. 2018). Detailed analysis may also prove the existence of cryptic species.

Two genera, Bradyagaue and Makarovana, are recorded from Norway but not from northern France or the United Kingdom/Eire area. Bradyagaue is wide-spread both in cold and warm water areas, also in the northern Atlantic, but the number of records is small. Most Bradyagaue species have been found in close association with the colonies of hydrozoa. Makarovana seems to be restricted to cold-water/polar areas. At least, the records of this genus are lacking from southern shores. In contrast, seven genera mentioned from the Roscoff area (France) (Acarochelopodia, Acaromantis, Actacarus, Agaue, Coloboceras, Copidognathides, Scaptognathus) and three genera from the Swedish Skagerrak area, from sediment samples taken at 5-25 m depth (Actacarus, Camactognathus, Coloboceras) (Bartsch 1991a), have no records from Norwegian waters. This absence will mainly be due to the sparse collecting activities in Norway; many habitats and substrata have never been studied.

Several but not all of the species mentioned from Norway have also been found on the French coast of the English Channel, around the United Kingdom and Eire (Table 2). The absence of records from areas outside Norway is partly due to the poor knowledge of the morphological characters of the species (e.g., Copidognathus latus, Lohmannella norvegica) and that the list of Nor- 


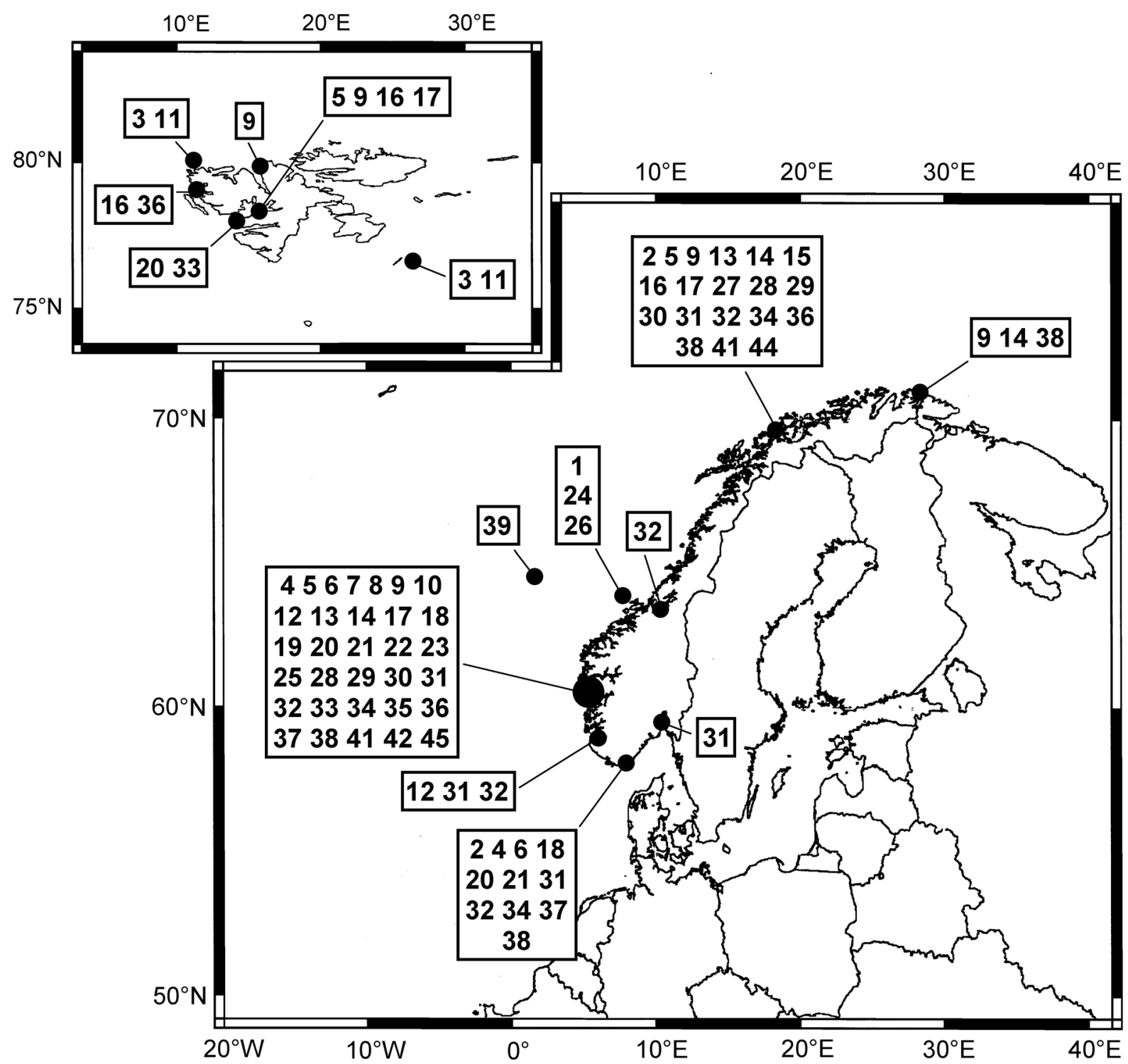

Fig. 1. Norway and adjacent countries, sampling sites and records of marine halacarid species. 1. Agauopsis corallina; 2. Anomalohalacarus minutus; 3. Bradyagaue alberti; 4. Copidognathus brevirostris; 5. C. brifacius; 6. C. fabricii; 7. C. latus; 8. C. oculatus; 9. C. reticulatus; 10. C. rhodostigma; 11. C. richardi; 12. Halacarellus balticus; 13. H. capuzinus; 14. H. floridearum; 15. H. procerus; 16. H. subcrispus; 17. H. subterraneus; 18. Halacarus bisulcus; 19. Isobactrus hartmanni; 20. I. levis; 21. I. setosus; 22. I. ungulatus; 23. Lohmannella falcata; 24. L. njoerdri; 25. L. norvegica; 26. L. sulensis; 27. Makarovana spinosa; 28. Maracarus gracilipes; 29. Metarhombognathus armatus; 30. Rhombognathides mucronatus; 31. R. pascens; 32. R. seahami; 33. R. spinipes; 34. R. trionyx; 35. Rhombognathus notops; 36. R. subtilis; 37. Simognathus minutus; 38. Thalassarachna basteri; 39. T. caecoides; 40. T. coeca; 41. T. hexacantha; 42. T. longipes; 43. T. princeps; 44. T. robusta; 45. T. striata.

wegian species includes samples from realms and habitats that have not been studied in the other areas (e.g., deep-sea substrata and cold water stony coral reefs). Both the species extracted from the Norwegian coral reefs and from deep-water zones will certainly also be found outside the Norwegian Exclusive Economic Zone.

In the list of Norwegian halacarids, the genera Copidognathus and Thalassarachna are represented by eight species each, Halacarellus and
Rhombognathides by six and five species, respectively. From a world-wide perspective, Thalassarachna, Rhombognathides and Metarhombognathus are preliminarily northern Atlantic cold-water genera (Bartsch 2004b). No reliable records of these genera exist from shores and shallows of the tropics. From the northern Pacific, a single record of a Thalassarachna exists, but none of Metarhombognathus and Rhombognathides. Halacarellus fauna is most diverse in cold-temperate and polar 
Table 2

Marine and freshwater halacarid genera with records from Norway, the United Kingdom and the Republic of Ireland (UK/Eire) and northern France (France). The number of species in these areas and presence $(\times)$ or absence (-) of the species known from Norway. (?-record in need of verification.)

Genus/Species

\section{Marine genera}

Acarochelopodia number of species

Acaromantis number of species Norway UK/Eire France

Actacarus

number of species

Agaue

number of species

Agauopsis number of species

A. corallina

Anomalohalacarus number of species

A. minutus

Bradyagaue number of species B. alberti

Coloboceras number of species

Copidognathides number of species

Copidognathus number of species

C. brevirostris

C. brifacius

C. fabricii

C. latus

C. oculatus

C. reticulatus

C. rhodostigma

C. richardi

Halacarellus number of species

H. balticus

H. capuzinus

H. floridearum

H. procerus

H. subcrispus

H. subterraneus

Halacarus

number of species

H. bisulcus

Isobactrus

number of species

I. hartmanni

I. levis

I. setosus

I. ungulatus
Genus/Species

Norway UK/Eire France

\section{Lohmannella}

number of species

L. falcata

L. njoerdri

L. norvegica

L. sulensis

Makarovana number of species M. spinosa

Maracarus number of species M. gracilipes

Metarhombognathus number of species M. armatus

Rhombognathides number of species

R. mucronatus

R. pascens

R. seahami

$R$. spinipes

R. trionyx

Rhombognathus number of species

$R$. notops

R. subtilis

Simognathus number of species S. minutus

Scaptognathus number of species

Thalassarachna number of species

T. basteri

T. caecoides

T. coeca

T. hexacantha

T. longipes

T. princeps

T. robusta

T. striata

Freshwater genera

Porohalacarus number of species P. alpinus

Porolohmannella number of species $P$. violacea

$\begin{array}{ccc}4 & 2 & 5 \\ \times & \times & \times \\ \times & - & - \\ \times & - & - \\ \times & - & - \\ & & \\ 1 & 0 & 0 \\ \times & - & - \\ & & \\ 1 & 2 & 2 \\ \times & \times & \times \\ & & \\ 1 & 2 & 1 \\ \times & \times & \times\end{array}$

$\begin{array}{ccc}5 & 5 & 6 \\ \times & \times & \times \\ \times & \times & \times \\ \times & \times & \times \\ \times & \times & \times \\ \times & \times & \times\end{array}$

$\begin{array}{ccc}2 & 2 & 5 \\ \times & \times & \times \\ \times & \times & \times\end{array}$

2

2

$4(-5 ?) \quad 3$

$\times \quad \times$

- $\quad-$

$\begin{array}{ll}- & - \\ - & -\end{array}$

$\times \quad-$

-

-

$\begin{array}{ll}- & -1 \\ - & -\end{array}$

$\times \quad \times$


waters, but poor in the tropics, both in the number of species and specimens (Bartsch 1997a, 2004b). Copidognathus holds, worldwide, almost one-third of all halacarid species. A checklist of halacarid species, dating to the end of 2008, included 1,118 species; 359 of these, or $32 \%$, belonged to Copidognathus (Bartsch 2009). A few new halacarid species, described in the last decade, do not seriously alter the percentage. In the Norwegian waters, the number of recorded Copidognathus species is low. Several more species are expected to be found, either new records or unknown species (e.g., one undescribed very slender species had been extracted from a small piece of a stony coral from the Sula Reef; personal observation).

With respect to freshwater, two species have been recorded from Norway, namely Porohalacarus alpinus and Porolohmannella violacea. From the central and northern parts of Sweden, seven freshwater species are known (Bartsch 1989b), from Great Britain eight species (Green and MacQuitty 1987) plus one (Halacarellus hyrcanus) solely represented by juveniles; their identity should be verified. The seven freshwater species recorded from Sweden, all of which are widespread, will certainly also be found in comparable habitats in Norway.

In conclusion, the present list of species shows that much more sampling has to be done to get a reliable idea of the present-day Norwegian halacarid fauna. Without solid basis, provided by more sampling, we will not be able to evaluate if the missing or new records in the fauna are a result of natural changes in a given ecosystem or human impact.

\section{ACKNOWLEDGEMENTS}

Thanks are due to M.Sc. Halldis Ringvold (Norway), who collected several of the halacarids mentioned, to Dr. Claude Poizat (France) and Dr. Reinhardt M. Kristensen (Denmark), who, in the course of their sampling programs, took care of halacarids and forwarded them to the author. Thanks are also due to Deutsches ElektronenSynchroton (DESY) for offering the author a work space in the institution, and of course to two unknown referees who have carefully read the manuscript and given useful hints.

\section{REFERENCES}

Anderson, F.R. 1933. The Halacaridae of Canso, N.S. Reports of the Biological Stations, vol. 93. 4 pp.

André, M. 1939. Sur trois espèces de Rhombognathus

(Halacariens) des côtes françaises. Bulletin $d u$
Muséum National d'Histoire Naturelle, Série 2, 11: 308-313.

André, M. 1946. Halacariens marins. Faune de France, 46: $1-152$.

Angelier, E. 1950. Halacarus (Halacarellus) petitihalacariens nouveau d'étang de salses (Pyrénées Orientales). Vie et Milieu, 1: 214-216.

Artsdatabanken. 2019. Kunskapsbank for naturmangfold. Artskart 1.6. Date of access: October, 212019. www.artsdatabanken.no

Bartsch, I. 1972. Ein Beitrag zur Systematik, Biologie und Ökologie der Halacaridae (Acari) aus dem Litoral der Nord- und Ostsee. I. Systematik und Biologie. Abhandlungen und Verhandlungen des Naturwissenschaftlichen Vereins zu Hamburg, Neue Folge, 16: 155-230.

Bartsch, I. 1973a. Halacaridae (Acari) von der Josephinebank und der großen Meteorbank aus dem östlichen Nordatlantik. I. Die Halacaridae aus den Schleppnetzproben. Meteor Forschungs-Ergebnisse, Reihe D, 13: 37-46.

Bartsch, I. 1973b. Porohalacarus alpinus (Thor) (Halacaridae, Acari), ein morphologischer Vergleich mit marinen Halacariden nebst Bemerkungen zur Biologie dieser Art. Entomologisk Tidskrift, 74: 116-123.

Bartsch, I. 1974a. Ein Beitrag zur Systematik, Biologie und Ökologie der Halacaridae (Acari) aus dem Litoral der Nord- und Ostsee. II. Ökologische Analyse der Halacaridenfauna. Abhandlungen und Verhandlungen des Naturwissenschaftlichen Vereins zu Hamburg, Neue Folge, 17: 9-53.

Bartsch, I. 1974b. Simogathus minutus (Hodge) (Halacaridae, Acari), eine Wiederbeschreibung nebst Bemerkung zur Unterfamilie der Simognathinae. Cahiers de Biologie Marine, 15: 275-284.

Bartsch, I. 1975a. Ein Beitrag zur RhombognathinenFauna (Halacaridae, Acari) der Bretagne-Küste. Acarologia, 17: 53-80.

Bartsch, I. 1975b. Ein Beitrag zum System der Rhombognathinae (Halacaridae, Acari). Zur Morphologie der Tarsalregion und des Ovipositors. Zoologischer Anzeiger, 194: 193-200.

Bartsch, I. 1976a. Beitrag zur Halacariden-Fauna (Halacaridae, Acari) der Bretagneküste. Beschreibung von fünf Arten aus dem Sandlückensystem. Acarologia, 17: 652-667.

Bartsch, I. 1976b. Zur Systematik und Verbreitung der Halacarellus-Arten (Halacaridae, Acari) an der Bretagne-Küste. Entomologische Mitteilungen aus dem Zoologischen Museum Hamburg, 5: 97-109.

Bartsch, I. 1976c. Ergänzung zur Halacariden-Fauna (Halacaridae, Acari) im Becken von Arcachon. Vie et Milieu, Série A, 26: 31-46. 
Bartsch, I. 1977a. Zur oculatus- und gibbus-Gruppe der Gattung Copidognathus (Halacaridae, Acari). Entomologische Mitteilungen aus dem Zoologischen Museum Hamburg, 6: 1-12.

Bartsch, I. 1977b. Ergänzung zur Halacariden-Fauna (Halacaridae, Acari) der Bretagne-Küste. Zur Gattung Arhodeoporus und Copidognathus. Acarologia, 18: 626-641.

Bartsch, I. 1978a. Halacaridae (Acari) von Gezeitenstränden Nordnorwegens. Mikrofauna des Meeresbodens, 70: 1-22.

Bartsch, I. 1978b. Halacaride (Acari) aus der Tiefsee des atlantischen Ozeans. Cahiers de Biologie marine, 19: 47-62.

Bartsch, I. 1978c. Verbreitung der Halacaridae (Acari) im Gezeitenbereich der Bretagne-Küste, eine ökologische Analyse. I. Verbreitung der Halacariden. Cahiers de Biologie marine, 19: 363-383.

Bartsch, I. 1979a. Verbreitung der Halacaride (Acari) im Gezeitenbereich der Bretagne-Küste, eine ökologische Analyse. II. Quantitative Untersuchungen und Faunenanalyse. Cahiers de Biologie marine, 20: 1-28.

Bartsch, I. 1979b. Ergänzungen zur CopidognathusFauna (Halacaridae, Acari) der Bretagne-Küste. Acarologia, 20: 217-234.

Bartsch, I. 1979c. Halacaridae (Acari) von der Atlantikküste Nordamerikas. Beschreibung der Arten. Mikrofauna des Meeresbodens, 79: 1-62.

Bartsch, I. 1980. Halacaridae (Acari) aus der Bucht von Morlaix (Bretagne). Acarologia, 21: 34-45.

Bartsch, I. 1982. Halacaridae (Acari) von der Atlantikküste des borealen Nordamerikas. Ökologische und tiergeographische Faunenanalyse. Helgoländer Meeresuntersuchungen, 35: 13-46.

Bartsch, I. 1983a. Copidognathus richardi (Trouessart) (Halacaridae, Acari), eine Wiederbeschreibung. Acarologia, 24: 285-288.

Bartsch, I. 1983b. Halacarellus coecus (Trouessart) und H. princeps (Trouessart) (Halacaridae, Acari), Wiederbeschreibung der Arten. Acarologia, 24: 49-57.

Bartsch, I. 1984. Ergänzungen zur Halacariden-Fauna der Bretagne-Küste und Beschreibung einer neuen Art (Halacaridae, Acari). Cahiers de Biologie Marine, 25: 113-122.

Bartsch, I. 1985a. Notes on the Halacaridae (Acari) from Yorkshire. Naturalist, 110: 41-48.

Bartsch, I. 1985b. Halacaridae (Acari) from the Strangford Narrows and the Irish Sea. Proceedings of the Royal Irish Academy, Section B, Biological, Geological and Chemical Science, 85(2): 21-35.

Bartsch, I. 1987. Zur Biologie, Ökologie und Verbreitung der süßwasserbewohnenden Halacaride $P_{O}$ - rohalacarus alpinus (Acari). Archiv für Hydrobiologie, 111: 83-93.

Bartsch, I. 1989a. Copidognathus brifacius n.sp. (Halacaridae, Acari) und Bemerkungen zu weiteren Bewohnern des Seeigels Spatangus purpureus (Echinoidea). Mitteilungen aus dem Hamburgischen Zoologischen Museum und Institut, 86: 315-328.

Bartsch, I. 1989b. Havskvalster (Acari, Halacaridae) i mellarsta och norra Sverige. Entomologisk Tidskrift, 110: 127-138.

Bartsch, I. 1991a. Taxonomic notes on halacarids (Acari) from the Skagerrak area. Helgoländer Meeresuntersuchungen, 45: 97-106.

Bartsch, I. 1991b. On the identity of some North Atlantic halacarid species (Acari). Journal of Natural History, 25: 1339-1353.

Bartsch, I. 1992. Bradyagaue stocki nov. spec., a deepsea halacarid mite (Halacaridae, Acari) from the Atlantic Ocean. Bulletin. Zoölogisch Museum, Amsterdam, 13(8): 81-84.

Bartsch, I. 1994. Halacarid mites (Acari) from hydrothermal deep-sea sites. New records. Cahiers de Biologie Marine, 35: 479-490.

Bartsch, I 1996. Rhombognathines (Acari: Halacaridae) of the Black Sea: a survey. Mitteilungen aus dem Hamburgischen Zoologischen Museum und Institut, 93: 141-160.

Bartsch, I. 1997a. Thalassarachna and Halacarellus (Halacaridae: Acari): two separate genera. Journal of Natural History, 31: 1223-1236.

Bartsch, I. 1997b. Copidognathus biodomus (Halacaridae: Acari), a new species from eastern Canada. Mitteilungen aus dem Hamburgischen Zoologischen Museum und Institut, 94: 153-159.

Bartsch, I. 1998. Halacarinae (Acari, Halacaroidea) from the northwestern Black Sea: a review. Mitteilungen aus dem Hamburgischen Zoologischen Museum und Institut, 95: 143-178.

Bartsch, I. 2001a. Agauopsis (Arachnida, Acari, Halacaridae) from the Northeastern Atlantic, description of two species, A. minor (Trouessart) and Agauopsis valida sp. nov. Mitteilungen aus dem Hamburgischen Zoologischen Museum und Institut, 98: 63-75.

Bartsch, I. 2001b. Black Sea Copidognathinae (Arachnida, Acari, Halacaridae): a review. Mitteilungen aus dem Museum für Naturkunde in Berlin, Zoologische Reihe, 77: 247-275.

Bartsch, I. 2003a. Halacarids (Acari) from coral reefs off Norway, Northern Atlantic: Description of a new Agauopsis species. Entomologische Mitteilungen aus dem Zoologischen Museum Hamburg, 14: 117-123.

Bartsch, I. 2003b. Lohmannellinae (Halacaridae: Acari) from the Great Meteor Seamount (Northeastern Atlantic). Description of new species and reflec- 
tions on the origin of the seamount fauna. Mitteilungen aus dem Hamburgischen Zoologischen Museum und Institut, 100: 101-117.

Bartsch, I. 2004a. The Black Sea halacarid fauna (Halacaridae: Acari): faunal comparison with the Mediterranean, Eastern North Atlantic, North Sea and the Baltic and reflection on its origin. Mitteilungen aus dem Museum für Naturkunde in Berlin, Zoologische Reihe, 80: 143-158.

Bartsch, I. 2004b. Geographical and ecological distribution of marine halacarid genera and species (Acari: Halacaridae). Experimental and Applied Acarology, 34: 37-58.

Bartsch, I. 2006a. Halacaroidea (Acari): a guide to marine genera. Organisms, Diversity \& Evolution, Electronic Supplement, 6: 1-104. http://www. senckenberg.de/odes/06-06.htm

Bartsch, I. 2006b. 5. Acari: Halacaroidea. In: R. Gerecke (Ed.). Süßwasserfauna von Mitteleuropa 7/2-1, Chelicerata: Araneae, Acari I. Elsevier, Spektrum, Heidelberg, pp. 113-157.

Bartsch, I. 2007a. The freshwater mite Porolohmannella violacea (Kramer, 1879) (Acari: Halacaridae), description of juveniles and females and notes on development and distribution. Bonner zoologische Beiträge, 55: 47-59.

Bartsch, I. 2007b. Halacarus longiunguis Police, 1909 (Acari: Halacaridae), a new record a century later, re-description and notes on Mediterranean Halacarus species. Entomologische Mitteilungen aus dem Zoologischen Museum Hamburg, 14: 393-403.

Bartsch, I. 2009. Checklist of marine and freshwater halacarid mite genera and species (Halacaridae: Acari) with notes on synonyms, habitats, distribution and descriptions of the taxa. Zootaxa, 1998: $1-170$.

Bartsch, I. 2011. North American freshwater Halacaridae (Acari): literature survey and new records. International Journal of Acarology, 37: 490-510.

Bartsch, I. 2015a. Halacaridae (Acari) amongst the epiflora and fauna on trunks, branches, roots, and pneumatophores on the coast of Singapore: a survey. The Raffles Bulletin of Zoology, Supplement 31: 96-138.

Bartsch, I. 2015b. Thalassarachna basteri and T. affinis (Acari, Halacaridae), history, characters, biology, and distribution. Ecologica Montenegrina, 2(3): 228-241.

Bartsch, I. 2015c. The genital area of Halacaridae (Acari), life stages and development of morphological characters and implication on the classification. Zootaxa, 3919: 201-259.

Bartsch, I. 2016a. Arhodeoporus, Camactognathus, Plegadognathus, and Winlundia (Acari: Halacari- dae), re-evaluation and geographical distribution. Acarologia, 56(4): 553-571.

Bartsch, I. 2016b. Antarctic Halacaridae (Acari), new records, these species characteristics and an updated list of species. Polish Polar Research, 37: 131-154.

Bartsch, I. 2017. The Halacarellus capuzinus group (Halacaridae: Acari), diagnoses, keys and a description of Halacarellus floridearum (Lohmann). Ecologica Montenegrina, 10: 71-87.

Bartsch, I. 2018. Freshwater halacarid mites (Acari: Halacaridae) from Madagascar - new records, keys and notes on distribution and biology. Bonn zoological Bulletin, 67 (2): 79-99.

Bartsch, I. 2020. Lohmannella (Acari, Halacaridae) from a cold-water coral reef off Norway, description of two new and a list of North Atlantic species. Zootaxa, 4722 (3): 277-286.

Bartsch, I. and Schmidt, P. 1979. Zur Verbreitung und Ökologie einiger Halacaridae (Acari) in Sandstränden der Ostsee (Kieler Bucht), der Nordsee (Sylt) und des Europäischen Nordmeeres (Tromsö). Mikrofauna des Meeresbodens, 74: 1-37.

Bartsch, I. and Smit, H. 2006. Een checklist van de Nederlandse Zeemijten (Acari: Halacaroidea). Nederlandse faunistische Mededelingen, 25: 25-32.

Baster, J. 1758. Observationes de Corrallinis, iisque infidentibus polypis, aliisque animalculis marinis. Philosophical Transaction of the Royal Society of London, 50: 258-279.

Bazan-Strzelecka, H. 1972. Wodopojki Hydracarina. Katalog fauny polski, 34 (8): 1-100.

Beusekom, J. van, Thiel, R., Bobsien, I., Boersma, M., Buschbaum, C., Dänhardt, A., Darr, A., Friedland, R., Kloppmann, M., Kröncke, I., Rick, J. and Wetzel, M. 2018. 5. Aquatische Ökosysteme: Nordsee, Wattenmeer, Elbeästuar und Ostsee. In: H. Storch, I. Meinke and M. Claußen (Eds.). Hamburger Klimabericht-Wissen über Klima, Klimawandel und Auswirkungen in Hamburg und Norddeutschland. Springer, Berlin, Heidelberg, pp. 89-107. DOI: 10.1007/978-3-662-55379-4_5

Bilio, M. 1966. Die aquatische Bodenfauna von Salzwiesen der Nord- und Ostsee. II. Ökologische Faunenanalyse: Hydrozoa, Nematodes, Rotatoria, Gastrotricha, Nemertini, Polychaeta, Oligochaeta, Halacaridae, Ostracoda, Copepoda. Internationale Revue der gesamten Hydrobiologie, 51: 174-182.

Brady, G. S. 1875. A review on the British marine mites with descriptions of some new species. Proceedings of the Zoological Society of London, 20: 301-311.

Briggs, J. C. 1974. Marine Zoogeography. McGrawHill, New York. 475 pp. 
Brinck, P., Dahl, E. and Wieser, W. 1955. On the littoral subsoil fauna of the Simrishamn beach in eastern Scania. Kungliga fysiografiska Sällskapets i Lund Förhandlingar, 25(14): 109-129.

Carlton, J.C., Blakeslee, A.M.H. and Fowler, A.E. 2020. Accidental associates are not symbionts: the absence of a non-parasitic endosymbiotic community inside the common periwinkle Littorina littorea (Mollusca: Gastropoda). Marine Biology, 167(7): 97.

Carriglio, D. 2010. Arachnida Acari: HalacaridaePontarachnidae: Biologia Marina Mediterranea, 17 (Supplement 1): 390-393.

Chatterjee, T., Dovgal, I., Pešić, V. and Zawal, A. 2018. A checklist of epibiont suctorian and peritrich ciliates (Ciliophora) on halacarid and hydrachnid mites (Acari: Halacaridae \& Hydrachnidia). Zootaxa; 4457 (3): 415-430.

Chertoprud, E.S., Makarova, O.L. and Novichkova, A.A. 2017. First data on aquatic mites (Acari) of inland water bodies of West Spitsbergen, Svalbard. Acarina, 25(2): 181-189.

Dahl, E. and Wieser, W. 1955. Two marine Halacaridae (Acari) new to the Swedish fauna, and remarks on the taxonomic status of a third species. Kungliga fysiografiska Sällskapets $i$ Lund Förhandlingar, 25(8): 66-72.

Dons, C. 1927. Neue und wenig bekannte Protozoen. Det Kongelig Norske Videnskabers Selskabs Skrifter, 1927(7): 1-17.

Dovgal; I., Chatterjee,T. and Ingole, B. 2008. An overview of suctorian ciliates (Ciliophora, Suctorea) as epibionts of halacarid mites (Acari, Halacaridae). Zootaxa, 1810: 60-68.

Durucan, F. 2018. 4.3 First record of Lohmannella falcata (Hodge, 1863) (Acari: Halacaridae) from the Mediterranean Sea of Turkey, Antalya. In: N. Chartosia, D. Anastasiadis, H. Bazairi, F. Crocetta, A. Deidun, M. Despalatović, V. Di Martino, N. Dimitriou, B. Dragičević, J. Dulčić, F. Durucan, D. Hasbek, V. Ketsilis-Rinis, P. Kleitou, L. Lipej, A. Macali, A. Marchini, M. Ousselam, S. Piraino, B. Stancanelli, M. Theodosiou, F. Tiralongo, V. Todorova, D. Trkov, and S. Yapici. New Mediterranean Biodiversity Records (July 2018). Mediterranean Marine Science, 19(2): 410-411.

Durucan, F. 2019a. New records of Copidognathus (Acari: Halacaridae) from Antalya, Turkey. Persian Journal of Acarology, 8(3): 189-210.

Durucan, F. 2019b. New halacarid records from Antalya, Turkey (Acari: Halacaridae). Munis Entomology and Zoology Journal, 14(1): 270-282.

Durucan, F. and Boyaci, Y.Ö. 2019. Contribution to the knowledge of freshwater halacarid mites (Acari:
Halacaridae) from Turkey. Acta Aquatica Turcica, 15(3): 318-324. DOI: 10.22392/actaquatr.515607

Flanders Marine Institute. 2018. Maritime Boundaries Geodatabase: Maritime Boundaries and Exclusive Economic Zones (200NM), v. 10. http://www. marineregions.org. DOI: 10.14284/312

Fountain, H.C. 1953. An examination of the original slides of marine Acari of Hodge, 1863. Journal of the Marine Biological Association of the United Kingdom, 32: 357-364.

Galassi, D.M.P., Stoch, F., Fiasca, B., Di Lorenzo, T. and Gattone, E. 2009. Groundwater biodiversity patterns in the Lessinian Massif of northern Italy. Freshwater Biology, 54: 830-847. DOI: 10.1111/j.1365-2427.2009.02203.x

Gollasch, S. and Nehring, S. 2006. National checklist for aquatic alien species in Germany. Aquatic Invasions, 1(4): 245-269.

Gosse, P.H. 1855a. Notes on some new or little-known marine animals (II). Annals and Magazine of Natural History, Series 2, 16(91): 27-36.

Gosse, P.H. 1855b. Notes on some new or little-known marine animals (III). Annals and Magazine of Natural History, Series 2, 16(91): 305-313.

Green, J. 1956. Additions to the British Halacaridae (Acari). Entomologist's monthly Magazine, 92:334.

Green, J. and MacQuitty, M. 1987. Halacarid Mites. Synopses of the British Fauna, New Series, vol. 36. 178 pp.

Hagerman, L. 1966. The macro- and microfauna associated with Fucus serratus L., with some ecological remarks. Ophelia, 3: 1-43.

Hedgpeth, J. W. 1957. Marine Biogeography. In: J.W. Hedgpeth (Ed.). Treatise on Marine Ecology and Palaeoecology I (13). The Geological Society of America, New York, pp. 359-382.

Hodge, G. 1860. Contributions to the marine zoology of Seaham Harbour. 1. On a new marine mite (Pachygnathus Seahami). Transactions of the Tyneside Naturalists' Field Club, 4(3): 319.

Hodge, G. 1863. Contributions to the marine zoology of Seaham Harbour. On some undescribed marine Acari. Transactions of the Tyneside Naturalists' Field Club, 5(4): 298-303.

Jarvekjul, A. 1979. Donnaya fauna vosttočnoi časti baltiiskogo morja. Balgus, Tallin, 382 pp.

Järvekülg, A. 1965. Mere- ja riimveeselgrotute levikupiiridest Matsula lahes. Eesti NSV Teaduste Akadeemia 14, Bioloogiline, Seeria 3:362-365. [Summary in Russian and German]

Johnston, G. 1836. Illustrations in British zoology. Magazine of Natural History, 9(63): 353-357.

Koçak, A.Ö. and Kemal, M. 2008. Nomenclatural notes on the genus group names of the order Acarina. 
Centre of Entomological Studies, Miscellaneous Papers, 145: 1-6.

Kramer, P. 1879. Ueber die Milbengattungen Leptognathus Hodge, Raphignathus Dug., Caligonus Koch und die neue Gattung Cryptognathus. Archiv für Naturgeschichte, 45: 142-157.

Krapivin, V.A. 2012. Symbionts of Mytilus edulis in the littoral and sublittoral zones of the Kandalaksha and Onega Gulfs of the White Sea. Parazitologiya, 46(3): 203-225.

Krivolutsky, D.A. and Antsiferova, M.P. 2008. Order Acariformes Zachvatkin 1952. In: E.D. Krasnova, A.V. Tchesunov, N.M. Kaljakina and E.N. Bubnova (Eds.). Catalogue of Biota of the MSU White Sea Biological Station. http://biota-en.wsbs-msu. ru/wiki/index.php/Catalogue

Linnaeus, C. 1758. Systema Naturae per Regna Tria Naturae. Editio decima. Impensis Laurentii Salvii, Holmiae, 824 pp.

Loebl, M., van Beusekom, J.E.E. and Reise, K. 2006. Is spread of the neophyte Spartina anglica recently enhanced by increasing temperatures? Aquatic Ecology, 40: 315-324.

Lohmann, H. 1889. Die Unterfamilie der Halacaridae Murr. und die Meeresmilben der Ostsee. Zoologische Jahrbücher, Abteilung für Systematik, Ökologie und Geographie der Tiere, 4: 269-408.

Lohmann, H. 1893a. Bemerkungen zu den auf der Holsatia-Fahrt 1887 gesammelten Halacarinen. Kommission zur wissenschaftlichen Untersuchung deutscher Meere, 6: 199-204.

Lohmann, H. 1893b. Die Halacarinen der PlanktonExpedition. Ergebnisse der Plankton-Expedition der Humboldt Stiftung, 2: G. a 11-95.

Makarova, N. G. 1978. [Marine mites (Acarina, Halacaridae) from the intertidal zone of the Gulf of Anadyr (Bering Sea)]. In: O.G. Kussakin (Ed.). The Intertidal Zone of the Bering Sea and SouthEastern Kamchatka. Nauka, Moscow, pp. 131149. [In Russian, with English summary]

Monniot, F. 1964. Sur deux espèces du genre Scaptognathus présentes à Roscoff. Acarologia, 6: 491-498.

Monniot, F. 1967. Deux halacariens endopsammiques: Halacarus anomalus Trouessart 1894 et Halacarus marcandrei n. sp. Cahiers de Biologie marine, 8: 82-98.

Morselli I. and Mari, M. 1985. Ricerche sugli alacaridi delle coste Livornesi. IV. — Osservazioni su alcune specie raccolte su fondi sabbiosi della zona di Piombino. Atti della Societa Toscana di Scienze Naturali, Memorie, Serie B, 91: 201-220.

Morselli I. and Mari, M. 1986. Nota breve su tre alacaridi (Acari, Prostigmata) di acque sotterranee
dell'Umbria. Atti della Societa dei Naturalisti e Matematici di Modena, 116: 77-78.

Motaş, C. 1961. Halacaridae. In: The Zoology of Iceland, Vol. III, part 55. Ejnar Munksgaard, Copenhagen and Reykjavik. 20 pp.

Murray, A. 1877. Economic Entomology. Aptera. South Kensington Museum Handbooks, 433 pp.

Newell, I.M. 1947. A systematic and ecological study of the Halacaridae of eastern North America. Bulletin of the Bingham Oceanographic Collection, 10: 1-232.

Newell, I.M. 1949. New genera and species of Halacaridae (Acari). American Museum Novitates, 1411: 1-22.

Newell, I.M. 1956. Pachygnathus notops Gosse 1855100 years later. Annals and Magazine of Natural History, Series 12(9): 465-475.

Newell, I.M. 1971. Halacaridae (Acari) collected during cruise 17 of the R/V Anton Bruun, in the southeastern Pacific Ocean. Anton Bruun Report, 8: 1-58.

Newell, I.M. and André, M. 1959. Révision des espèces de Rhombognathus (Halacariens marins), décrites par Édouard L. Trouessart. Acarologia, 1: 124-146.

Nikitina, M.P. 2013. Sezonnaya dinamika chislennosti i zhiznennye tsikly morskich kleschey litoralnykh fukoidov v okrestnostyakh BBS [Seasonal population dynamics and life cycles of marine ticks of littoral fucoids in the vicinity of the BBS]. Materialy nauchnoy konferentsii "Morskaya biologiya, geologiya, okeanologiya-mezhdistsiplinarnye issledovaniya na morskikh statsionarakh”, posvyashch. 75-letiyu Belomor. biol. stantsii im. N.A. Pertsova (27 February-1 March 2013). Lomonosov Moscow State University, Moscow, pp. 207-212, Table 1. [In Russian]

Packard, A.C. 1871. On insects inhabiting salt water. American Journal of Science, 3: 100-110.

Pepato, A.R. and da Silva Conceição, P.H. 2020. Chapter 16. Halacaroidea. In: C. Damborenea, J.H. Thorp and D.C. Rogers (Eds.). Thorp and Covich's Freshwater Invertebrates, Fourth Edition, Volume 5, Keys to Neotropical and Antarctic Fauna. Elsevier Science, pp. 540-544.

Pešić, V. 2004. Three interesting halacarid mite species (Acari: Halacaroidea) from Montenegro and Italy. Lauterbornia, 49: 37-42.

Petrova, A. 1972. Sur la présence d'Halacarellus subterraneus Schulz, 1933 et Halacarellus phreaticus n. sp. (Halacaridae, Acari) en Bulgarie. Acarologia, 13: 367-373.

Police, G. 1909. Alcune nuove specie di Halacaridae del Golfe di Napoli. Archivio Zoologico, Napoli, 3: 409-443. 
Pugh, P.J.A. 1988. The shore-dwelling Acari of the Isles Scilly and the South-West Peninsula. Journal of Natural History, 22: 931-948.

Pugh, P.J.A. and King, P.E. 1985. Vertical distribution and substrate association of the British Halacaridae. Journal of Natural History, 19: 961-968.

Riesgo, A., Pérez-Portela, R. and Arroyo, N.L. 2010. Halacarid mites (Acari: Halacaridae) associated with a North Atlantic subtidal population of the kelp Laminaria ochroleuca. Journal of Natural History, 44(11): 651-667.

Schmidt, P. 1972. Zonierung und jahreszeitliche Fluktuationen der interstitiellen Fauna in Sandstränden des Gebietes von Tromsö (Norwegen). Mikrofauna des Meeresbodens, 12: 81-164.

Schröder, O. 1907. Die Infusorien der deutschen Südpolarexpedition 1901-1903. Deutsche Südpolarexpedition 1901-1903, Zoologie; 9(5): 352-360.

Schulz, E. 1933a. Beiträge zur Kenntnis mariner Suctorien. Zoologischer Anzeiger, 103: 327-329.

Schulz, E. 1933b. Zur Halacaridenfauna der Kieler Bucht. Schriften des Naturwissenchaftlichen Vereins für Schleswig-Holstein, 20: 96-105.

Sellnick, M. 1949. Milben von der Küste von Schweden. Entomologisk Tidskrift, 70: 123-135.

Semenchenko, K.A., Abé, H. and Boeskorov, G.G. 2010. New data on the water mite fauna (Acari, Hydrachnidia, Halacaroidea) of the Sakha Republic (Yakutia). Entomological Review, 90(2): 218-229.

Smit, H., van Haaren, T. and Tempelman, D. 2010. Checklist of water mites (Acari: Hydrachnidia and Halacaridae) of the Baltic states. Latvijas Entomologs, 48: 52-75.

Sokolov, I.I. 1946. [New species of Halacaridae from the Arctic Ocean.] In: Trudy dreifuyuschey ekspeditsii glavsevmorputi na ledokolnom parokhode 'G. Sedov' 1937-1940 gg. 3. NAUKA, Moscow, Leningrad, pp. 302-307. [In Russian, with English translation]

Sokolov I.I. 1952. Vodyanye kleschi. II. Halacarae. Fauna SSSR, 5. Izdatelstvo Akademii Nauk SSSR, Moscow, Leningrad. 201 pp.

Somerfield, P. 1988. New records of marine Halacaridae (Acari: Prostigmata) from rocky shores around the Irish coast. Bulletin of the Irish biogeographical Society, 11: 6-21.

Somerfield, P. 1991. Additional records of marine Halacaridae (Acari: Prostigmata) from Ireland. Bulletin of the Irish biogeographical Society, 14: 2-23.

Svenonius, B. 1949. Über die Hydracarinenfauna im Bottenviken und im angrenzenden Küstengebiet. Entomologisk Tidskrift, 70: 253-256.

Stolbov, V.A., Popova, V.V., Sheikin, S.D. and Tupitsyn, S.S. 2018. Water mites (Acariformes: Hydrach- nidia, Halacaroidea) of bogs of Western Siberia (Russia). Ecologica Montenegrina, 18: 102-109.

Thor, S. 1910. Die erste norwegische Süßwasserform der Halacariden. Zoologischer Anzeiger, 36: 348-351.

Thor, S. 1922. Neue Acarina-Formen aus meinen älteren Sammlungen, nebst Bemerkungen über Arten, Gattungen und Familien. Nyt Magasin for Naturvidenskaberne, 61, 91-118.

Tolstikov, A.V., Vvedenskaya, T.L., Stolbov, V.A. 2005. Preliminary data on the fauna of fresh-water mites (non-Parasitengona) of the Kamchatka Peninsula. Vladimir Ya. Levanidov's Biennial Memorial Meetings, 3: 309-311. [In Russian, with English Summary]

Trouessart, E.L. 1888. Note sur les acariens marins recueillis par M. Giard au laboratoire maritime de Wimereux. Comptes Rendus de l'Académie des Sciences, Paris, 107: 753-755.

Trouessart, E. 1889a. Sur les acariens marins des côtes de France. Comptes Rendus de l'Académie des Sciences, Paris, 10: 1178-1181.

Trouessart, E. 1889b. Revue synoptique de la famille des Halacaridae. Bulletin Scientifiques de la France et de la Belgique, Série 3, 20: 225-251.

Trouessart, E. 1893. Note sur les acariens recueillis au Spitzberg pendant le voyage de la Manche. Nouvelles Archives des Missions Scientifiques Littéraires, 5: 255-263.

Trouessart, E. 1894a. Note sur les acariens marins (Halacaridae) dragués par M.P. Hallez dans le Pasde-Calais. Revue Biologique du Nord de la France, 6: 154-184.

Trouessart, E. 1894b. Révision des Acariens des règions arctiques et description d'espèces nouvelles. Memoirs du Museum national des Sciences Naturelles et Mathématiques de Cherbourg, Série 3, 9, 29: 183-200.

Trouessart, E.L. 1894c. Note sur les acariens marins (Halacaridae) récoltés par M. Henri Gadeau de Kerville sur le littoral du départment de la Manche (Juillet-Août 1893). Bulletin de la Société Amis des Sciences Naturelles, Rouen, 9: 139-175.

Trouessart, E.L. 1896. Halacariens. Résultats scientifiques de la Campagne du 'Caudan' dans le Golf de Gascogne. Annales de l'Université de Lyon, 26: 325-353.

Trouessart, E.L. 1899. Description d'espèces nouvelles d'Halacaridae. Bulletin de la Société d'Études Scientifiques d'Angers, 29: 209-223.

Trouessart, E.L. 1901. Note sur les Acariens marins (Halacaridae) récoltés par M. Henri de Gadeau de Kerville dans la région d'Omonville-la-Rogue (Manche) et dans la fosse de la Hague. Bulletin de la 
Société Amis des Sciences Naturelles, Rouen, Série 4, 14: 247-266. [Trouessart, E. \& Neumann, G.]

Trouessart, E. 1902. Note préliminaire sur les acariens marins (Halacaridae) recueillis par S.A.S. le Prince de Monaco, dans les mers arctiques. Bulletin de la Société Zoologique de France, 27: 66-70.

Viets, K. 1927a. Die Halacaridae der Nordsee. Zeitschrift für wissenschaftliche Zoologie, 130: 83-173.

Viets, K. 1927b. Halacaridae. Tierwelt der Nord- und Ostsee, XI:c, 1-72.

Viets, K. 1927c. Mitteilung über das Vorkommen von Halacariden in der Kiemenhöhle von Flußkrebsen. Verhandlungen. Internationale Vereinigung für theoretische und angewandte Limnologie, 3: 460-473.

Viets, K. 1928a. Die Halacariden des Schärgaards bei Bergen (Norwegen). Bergens Museum Aarbok 1927, Naturvidenskapelig rekke, 6: 1-14.

Viets, K. 1928b. Halacaridae von der Murman-Küste, aus dem Weissen Meer und von Nowaja-Semlja. Issledovanja Morei SSSR, 6: 81-88.

Viets, K. 1933a. Kleine Sammlungen in- und ausländischer Wassermilben. Zoologischer Anzeiger, 104: 261-274.

Viets, K. 1933b. Vierte Mitteilung über Wassermilben aus unterirdischen Gewässern (Hydrachnellae et Halacaridae, Acari). Zoologischer Anzeiger, 102: 277-288.

Viets, K. 1936. C. Die Meeresmilben. Halacaridae Murray, 1876. In: K. Viets (Ed.). Spinnentiere oder Arachnoidea. VII. Wassermilben oder Hydracarina (Hydrachnellae und Halacaridae). Tierwelt Deutschlands, vols. 31, 32, pp. 516-559.
Viets, K. 1937. Wassermilben aus nordostspanischen Höhlengewässern. (11. Mitteilung über Wassermilben aus unterirdischen Gewässern.) Archiv für Hydrobiologie, 31: 553-564.

Viets, K. 1940. Meeresmilben aus der Adria (Halacaridae und Hydrachnellae, Acari). Archiv für Naturgeschichte (Neue Folge), 9: 1-135.

Viets, K. 1956. Die Milben des Süßwassers und des Meeres. Katalog der Halacaridae, Meeresmilben. II. Abschnitt. In: K. Viets (Ed.). Die Milben des Süßwassers und des Meeres. Hydrachnellae et Halacaridae. Fischer Verlag, Jena, pp. 641-870.

Viets, K.O. 1987. Die Milben des Süßwassers (Hydrachnellae und Halacaridae (part.), Acari). 2. Katalog. Abhandlungen des Naturwissenschaftlichen Vereins zu Hamburg, Sonderband 8: 1-1012.

Weinstein, F. 1961. Présence a Banyuls-sur-Mer (Pyrénées-Orientales) de Halacarus bisulcus Viets. Bulletin du Muséum National d'Histoire Naturelle, 2e Série 53(2): 208-212.

Willmann, C. 1952. Die Milbenfauna der Insel Wangerooge. Veröffentlichungen des Instituts für Meeresforschung in Bremerhaven, 1: 139-186.

Witte, S., Buschbaum, C., van Beusekom, J.E.E. and Reise, K. 2010. Does climatic warming explain why an introduced barnacle finally takes over after a lag of more than 50 years? Biological Invasions, 12: 3579-3589

Zawal, A. 1998. Water mites (Hydracarina) in the branchial cavity of crayfish Orconectes limosus (Raf. 1817). Acta Hydrobiologica, Cracow, 40: 49-54.

Źmudziński, L. 1974. Świat Zwierzęcy Baltyku. Wydawnictwa Szolne i Pedagogiczne, Warszawa. 216 pp. 